\title{
Current Perspectives on Immunomodulation of NK Cells in Melanoma
}

\author{
Tadepally Lakshmikanth and Maria H. Johansson \\ Department of Microbiology, Tumor and Cell Biology, \\ Karolinska Institutet, Stockholm, \\ Sweden
}

\section{Introduction}

Malignant Melanoma is a highly aggressive, deadly, chemoresistant and difficult-to-treat form of skin cancer (Flaherty and Gadgeel, 2002), which develops as a consequence of multifactorial perturbations from a series of architectural and phenotypically distinct stages, finally culminating into metastasis. It continues to increase in most western countries amongst the white population, the incidence has been increasing yearly by $5-7 \%$ and the prognosis for this metastatic disease remains poor (Greenlee et al., 2001). Melanoma incidence is influenced by pigmentation of the population as well as geographical parameters such as latitude and altitude (Armstrong and Kricker, 2001). According to epidemiological and experimental studies, the major risk factor of melanoma is ultraviolet radiation, which is associated with intermittent burning doses, especially during childhood (Whiteman et al., 2001). Melanoma is usually diagnosed at an early stage and is amenable to primary surgical treatment. However, it is sometimes characterized by an aggressive disease course with widespread metastasis and poor prognosis, which does not respond to standard therapy. Melanoma is largely refractory to current adjuvant therapies including chemotherapy, radiation therapy and/or immunotherapy (Chin et al., 2006) and therefore remains as a significant cause of mortality in Caucasians.

Immune responses are believed to have an important function in the natural history of melanoma since tumor infiltrating lymphocytes (TILs) are commonly found in melanoma, often associated with spontaneous regression and considered a favorable prognostic factor in primary melanoma (Mackensen et al., 1994). Hence, melanoma is the most studied tumor model in the field of human tumor immunology. NK cells represent a critical first line of defense against malignant transformation. NK cells were identified in melanoma in the 80s by Kornstein (Kornstein et al., 1987). Tumor immune surveillance allows recognition and destruction of cancer (host-protective) but may also shape cancer immunogenicity (tumorpromoting) through a 'cancer immunoediting process' due to selective pressure from the immune system. We have shown evidence for an immunoediting process enabling melanoma cells to escape from NK cell recognition (Lakshmikanth et al., 2009). In this chapter, we have taken into consideration the work accomplished by many investigators in trying to understand the immunology of melanoma and to identify various treatment strategies. The immune system basically has two main possibilities for dealing with malignant tissue which are Antigen (Ag)-specific CTLs and Ag-non-specific immune 
response by NK cells. We here put forth current perspectives on therapeutical strategies used against melanoma with specific focus on NK cells and provide insights into new opportunities for NK cell-based immunotherapy of melanoma disease.

\section{NK cells and their role in melanoma}

NK cells comprise approximately $10-15 \%$ of peripheral blood lymphocytes in human and are known to kill transformed cells and produce cytokines critical to the innate immune response (Cooper et al., 2001). NK cells are found in peripheral tissues, including the liver, peritoneal cavity and placenta. Resting NK cells circulate in the blood, but following activation by cytokines, they are capable of extravasation and infiltration into most tissues that contain pathogen-infected or malignant cells (Morris and Ley, 2004). NK cells were originally described based on their ability to lyse certain tumors in the absence of prior stimulation (Herberman et al., 1975; Kiessling et al., 1975a). NK cells may play a role in antitumor surveillance (Kiessling et al., 1975b), in vivo rejection of tumor cells (Porgador et al., 1995) and prevention of tumor metastases (Taniguchi et al., 1985). Much knowledge has been acquired with respect to origin, differentiation, receptor repertoire and effector functions of NK cells, as well as to their ability to shape adaptive immune responses (Colucci et al., 2003). NK cells induce target cell lysis and apoptosis in a cell-contactdependent manner through release of cytotoxic granules containing perforin and granzymes (Trapani et al., 2000), and/or ligands engaging death receptors on the target cell, such as Fas or TRAIL-R (Lieberman, 2003). In addition, NK cells can secrete a number of effector cytokines such as interferon- $\gamma$ (IFN- $\gamma$ ) which play critical roles in antiviral defense as well as in tumor surveillance (Biron et al., 1999; Street et al., 2001), tumor necrosis factor-a (TNF-a), granulocyte-macrophage colony stimulating factor (GM-CSF), Interleukin (IL)-5, IL-10 and IL-13, all of which influence adaptive immune responses (Loza et al., 2002). NK cells respond to a variety of cytokines, such as IL-2 (Talmadge et al., 1987), IL-12 (Trinchieri, 1998), IL-15 and Type I IFNs ( $\alpha$ and $\beta$ ) (Santoni et al., 1985), which increase their cytolytic, secretory, proliferative and antitumor functions. NK cells express a variety of adhesion molecules like integrins, selectins (Morris and Ley, 2004), and immunoglobulin (Ig) superfamily molecules like DNAM-1 (CD226) (Shibuya et al., 1996), aiding migration to peripheral tissues (Colucci et al., 2003), and infiltration of tumors (Fogler et al., 1996).

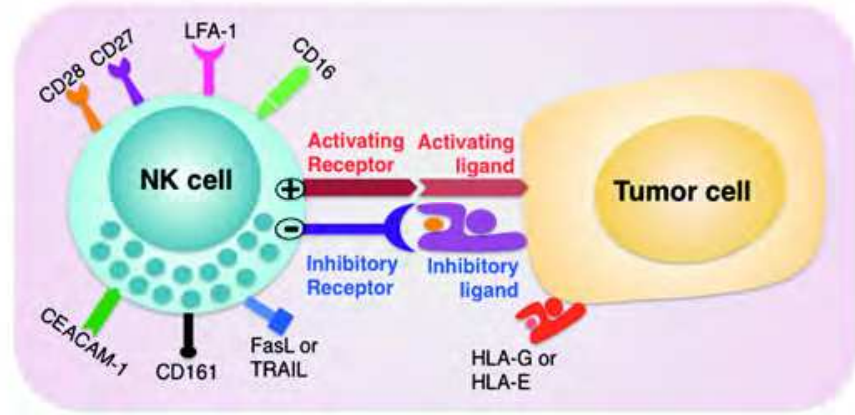

Fig. 1. A schematic figure showing interaction of a human NK cell with a tumor target by ligation of NK cell activating receptors and inhibitory receptors with corresponding ligands on the targets. Activating receptors include NCRs, NKG2D or DNAM-1. Inhibitory receptors are KIRs and CD94/NKG2A. 


\subsection{NK cell recognition}

NK cells utilize several parallel recognition mechanisms to distinguish and eliminate aberrant cells (Karre, 1991; Lanier, 2005). Recognition is based on an array of activating and inhibitory receptors. Activating receptors often bind to cognate ligands that are upregulated on 'stressed' cells (e.g. tumor or virus-infected cells), while the major inhibitory receptors bind to MHC class I molecules which may be down-regulated on tumors and virus-infected cells, referred to as 'missing-self' recognition (Fig 1) (Ljunggren and Karre, 1990).

Activating NK receptors mainly involved in tumor cell lysis are represented by the Fcyreceptor, CD16 (Lanier, 2005), the NKp46, NKp30, and NKp44 (collectively called natural cytotoxicity receptors; NCRs), all belonging to the Ig superfamily (Moretta et al., 2001). There is limited information on the ligands for NCRs with the exception of B7-H6 ligand recognized by NKp30 (Pogge von Strandmann et al., 2007). In addition, C-type lectin-like receptors like NKG2D are expressed by NK cells as well as CTLs. NKG2D recognizes the stress inducible MICA/B and ULBP proteins (Lanier, 2005). DNAM-1 is expressed by NK cells, partially expressed by $\mathrm{T}$ lymphocytes and monocytes and recognizes PVR (CD155) and Nectin-2 (CD112) (Bottino et al., 2003). The activating receptors have a short cytoplasmic tail without signaling motifs and associate with adaptor proteins via charged amino acids in their transmembrane domains. Adaptor proteins contain the immune receptor tyrosine-based activation motifs (ITAMs), which get phosphorylated upon receptor engagement and recruit tyrosine kinases, leading to activation of lymphocytes. Synergy between different activating receptors is important in activation of naive NK cells by target cells. Engagement of specific combinations of receptors govern the degree of activity but also dictates qualitatively distinct events, such as target cell adhesion, granule polarization and NK cell degranulation (Bryceson et al., 2005). A large number of adhesion and costimulatory molecules such as CD2, CD7, CD161, CD59, NTB-A, CD62L, NKp80, and LFA-1 also play an important role in fine tuning the NK cell activity (Lanier, 2005).

Inhibitory NK receptors ligate major histocompatibility (MHC) molecules to modulate the immune response. Human NK cell inhibitory receptors that recognize antigens encoded by the HLA-A, -B, -C loci are members of the Ig superfamily and termed Killer immunoglobulin-like receptors (KIRs) (Long, 1999). Other receptor families include natural killer group 2 (NKG2) which are C-type lectins that heterodimerize with CD94 and recognize non-classical HLA-E molecules. Engagement of inhibitory receptors can turn an NK cell off via intracellular signaling mediated through phosphorylation of immunoreceptor tyrosine-based inhibitory motifs (ITIMs) in their cytoplasmic tail (Lanier, 2005). In contrast, the absence or incomplete expression of host MHC class I molecules will result in lack of inhibition and render a cell susceptible to NK cell attack (Ljunggren and Karre, 1990).

NK cell response thus depends on the net effect of activating and inhibitory receptors and is regulated through a balance between positive and negative signals. NK-mediated killing can occur if the target cell expresses appropriate activating ligands and/or lacks inhibitory ligands (Lanier, 2005). Stimulation is initiated through a combination of signals from multiple receptor/ligand interactions, which initiates several signaling cascades, resulting in cytokine secretion and release of cytolytic granules (Davis and Dustin, 2004).

\subsection{NK cells in melanoma}

Melanoma is the most studied tumor model in tumor immunology since it responds to various immunotherapeutic approaches and displays spontaneous regressions (Lotze et al., 
1992). Immunotherapy treatment-related skin depigmentation is considered a favorable prognostic sign during melanoma intervention. NK cells were identified as important effectors in the host defense against melanoma in the 80s (Trinchieri and Perussia, 1984). Experiments demonstrated that loss of HLA-I expression in melanoma cell lines, accompanied by escape from autologous CTLs, sensitized targets for NK cell attack (Pandolfi et al., 1991). NK cells, being present in the skin and able to sense stress-induced ligands on premalignant cells, may be important early before clinically detectable malignancy arises (Luci et al., 2009). NK cells could thus orchestrate a response in the microenvironment before overt tumor transformation (Strid et al., 2008). Some studies have reported that NK cells were less represented in TILs (Lakshmikanth et al., 2009; Vetter et al., 2002) while others have reported frequent NK cells in malignant melanoma specimens (Becker et al., 2000; Kornstein et al., 1987). NK cells play a critical role in tumor immunosurveillance (Smyth et al., 2002). A role for NK cells in the control of hematogenous dissemination and growth of melanoma metastases was observed by Kornstein (Kornstein et al., 1987). Animal models have demonstrated a critical role in preventing the establishment of metastatic disease dependent on IFN- $\gamma$ and perforin (Kim et al., 2011; Markovic and Murasko, 1991). The involvement of NK cells in antitumor immunity in vivo was demonstrated in several mouse tumor models using NK cell-depleting antibodies and genetically modified mutant mice (Diefenbach et al., 2001; Shankaran et al., 2001; Smyth et al., 2002). Using the B16 murine melanoma model, NK cells were shown to be major mediators of the natural control of both spontaneous and experimental metastatic dissemination (Markovic and Murasko, 1990). Defects in NK activity in patients with metastatic disease have been described (Muller et al., 1989), however, there is no correlation between NK activity and prognosis in melanoma patients (Hersey et al., 1980). Some studies have shown a decrease in NK cell activity of all melanoma patients, associated with advancing stage of melanoma disease (Sibbitt et al., 1984) and due to IL-10 and TGF- $\beta$ (Jovic et al., 2001).

To date, little substantial information exists on the ability of autologous NK cells to kill melanoma tumors. One study shows efficient autologous NK-mediated lysis of HLA class I negative melanoma cells in patients undergoing specific T cell-therapy (Porgador et al., 1997). The susceptibility of melanoma cells obtained from patients to autologous NK cells and the role of activating/inhibitory receptors were comprehensively analyzed in one study (Carrega et al., 2009). However, there are no reports on autologous NK lines as a potential tool for treatment of melanoma patients. As loss of MHC class I expression renders tumor cells more sensitive to NK cell killing, it may be associated with improved prognosis in melanoma (Porgador et al., 1997). There is evidence for susceptibility of melanoma cells to NK-mediated lysis due to insufficient amounts of HLA class I molecules (Pende et al., 1998). Some of our recent work points towards strategies for NK cell-based immunotherapy. These will be explained more in detail in a later section. First, in the B16-F10 mouse melanoma model, blockade of mouse NK cell inhibitory NK receptors (Ly49), mimicking a 'missing self' phenotype, in combination with IL-2 treatment significantly delayed outgrowth of established sub-cutaneous tumors in an NK cell-dependent manner (Vahlne et al., 2010). Second, syngeneic mouse NK cells, autologous human NK cells, and allogeneic NK cells from healthy donors were shown to have the intrinsic capacity to recognize and target melanoma cells. Further, autologous and allogeneic NK cells preferentially targeted lymph node (LN) melanoma metastases over metastases from skin, pleura and liver. The NCRs and DNAM-1 emerged as key receptors in directing the NK anti-melanoma cytotoxicity 
(Lakshmikanth et al., 2009). These results have implications in patients with melanoma for the design of immunotherapeutic strategies.

A major part of melanoma patients are of old age. It is therefore important to consider agedependent changes in the immune system in relation to immunotherapy of melanoma. With increasing age, the number of NK cells seems to increase. However, the killing activity of naive NK cells was decreased in some studies, but could sometimes be fully restored by IL-2 activation (Le Garff-Tavernier et al., 2010). NK cells from older donors may, however, require higher concentrations of IFN- $\alpha$ for activation (Burns and Leventhal, 2000).

\section{Receptor-ligand interactions involved in NK cell recognition of melanoma}

Lack of inhibition and recognition of activating structures on target cells are the key events to prime NK cell-mediated cytotoxicity and cytokine production (Bryceson et al., 2006). Therefore, integration of signals derived from multiple activating and inhibitory receptors regulates the NK recognition of tumors but the relative importance of different receptors varies between different cancerous situations (Farag and Caligiuri, 2006). The main activating NK cell receptors as described in section 2.1 are NCRs, NKG2D and DNAM-1. Signaling through these receptors has been shown to be important in NK recognition of melanoma that expresses ligands for these activating receptors (Lakshmikanth et al., 2009; Solana et al., 2007). The importance of ligands for the NCRs has been demonstrated by use of blocking monoclonal antibodies in vitro in several studies (Pende et al., 1999). Results from blockade of two or more NCRs indicate that multiple NCRs are involved in NK recognition of melanoma (Lakshmikanth et al., 2009; Pende et al., 1999). The importance of NCR in disease progression in vivo has been demonstrated in NKp46-deficient mice, which developed more lung colonies than wild type mice, when melanoma cells were transferred intravenously (Lakshmikanth et al., 2009). NK cells along with CD8 ${ }^{+}$and $\gamma \delta T$ cells express NKG2D (Hayakawa and Smyth, 2006). The role of NKG2D in NK recognition of melanoma cells has been demonstrated, as well as a correlation between NKG2D function and expression of ligands on melanoma cells (Pende et al., 2002). Recent observations show that the ligands, MICA/B, may be downregulated in metastatic lesions (Vetter et al., 2002), but there are contrasting data (Markel et al., 2009), as well as data showing heterogeneity in NKG2D ligand expression (Lakshmikanth et al., 2009). It is therefore important to understand if NKG2D ligand expression changes with disease progression. The DNAM-1 receptor is important in recognition of freshly isolated cells from melanoma by NK cells. In vivo interference of DNAM-1 by antibody-mediated blockade or genetic ablation compromises rejection of melanoma cells in transplanted mice (Gilfillan et al., 2008; Lakshmikanth et al., 2009). PVR and Nectin-2 ligands were recently shown to bind also to T cell immunoglobulin and ITIM domain (TIGIT), a recently identified inhibitory receptor that counteracts the activating effects of DNAM-1 (Yu et al., 2009). Potential modulation of DNAM-1 ligands during melanoma disease progression requires further investigation. The relative roles of NCRs, NKG2D or DNAM-1 in NK cell recognition will vary depending on the expression of relevant ligands on tumors. Effective lysis is often seen when DNAM-1 is triggered in concert with other activation receptors, typically NCRs and/or NKG2D (Bryceson et al., 2006; Pende et al., 2001). Synergistic effects between different receptors have been demonstrated in melanoma (Carrega et al., 2009; Casado et al., 2009; Lakshmikanth et al., 2009) showing that in the absence of ligands for a particular receptor, other receptors would synergize for the complete eradication of the tumor. Similar findings were reported for suppression of poorly immunogenic melanoma metastases (Chan et al., 2010). 
Melanoma cells also express death receptors that bind to ligands belonging to the Tumor necrosis factor (TNF) family: TNF- $\alpha$, FAS ligand (FASL), TNF-related apoptosis-inducing ligand (TRAIL) and TNF-weak inducer of apoptosis (TWEAK) expressed on lymphocytes. Interaction with ligands on lymphocytes results in activation of the caspase pathway and apoptosis. This kind of ligand-receptor mechanism has been shown to be important in tumor recognition in vivo (Smyth et al., 2002).

\section{Immunosurveillance of melanoma and cancer metastasis}

Most patients with solid tumors die due to metastatic spread of the disease. Metastatic cells have a highly unstable phenotype and can rapidly adapt to selective pressure, allowing the cells to survive even under the most unfavorable circumstances (Meier et al., 1998). We have recently shown that melanoma metastases obtained from different anatomical sites of human melanoma patients display differential susceptibilities to NK cell lysis in relation to their phenotypic expression profile. Tumor metastasis of cutaneous melanoma is a stepwise process; where the tumor cells first colonize the lymph nodes, then enter the systemic circulation and reach remote tissues like skin, brain, lungs or liver. During the local invasion and metastatic spread of melanoma, invasive characteristics appear. Tumor cells then dissociate from the primary lesion, migrate through the surrounding stroma, and invade blood vessels and lymphatics (Haass et al., 2005). Most cancers spread early through the lymphatic vessels to lymph nodes, which can be a source of further metastases through the blood stream to the viscera, where development of secondary tumors can affect vital functions and cause death (Cochran et al., 2006). Tumors may even influence immune cells in adjacent lymph nodes. Significant differences were shown in lymphocyte subpopulations between different lymph nodes of patients with melanoma, with a marked decrease in the number of CD4+ T helper $\left(\mathrm{T}_{\mathrm{H}}\right)$ and an increase in the number of CD56+ NK cells, which correlated with the clinical stage of melanoma, distance of the node from the primary tumor and the tumor status of the node (Farzad et al., 1990). There are also reports on reduced lymphocyte activity as well as immune inhibitory activity from cells in lymph nodes close to tumors (Wen et al., 1989). This may facilitate the establishment and expansive growth of metastatic tumors in lymph nodes (Cochran et al., 2001).

\subsection{Mechanisms of tumor escape from Immune surveillance}

Downregulation of MHC class I molecules to escape CTL recognition is a process well known to occur in solid tumors during metastatic progression (Marincola et al., 2000). This can remarkably sensitize tumor cells to NK-mediated lysis (Ferrone and Marincola, 1995). However, owing to the selective pressure posed by NK cells, tumors have evolved various mechanisms by which they can evade NK cell attack. These mechanisms include interference with NK cell activation or adhesion, induced inhibition as well as modulation of NK cell function.

\section{Modulation of recognition via activating receptors}

The MICA/B proteins are recognized by the activating receptor, NKG2D. Loss of MICA/B proteins during uveal melanoma tumor progression has been shown to occur, suggesting an immune selection of MIC-negative tumor variants with reduced NK sensitivity (Vetter et al., 2004). There is evidence for strong immunoediting of tumors by NK cells. The phenomenon has been well studied in receptor knock out mice for NKG2D (Guerra et al., 2008; Smyth et 
al., 2005) or DNAM-1 (Iguchi-Manaka et al., 2008) or NKp46 (Elboim et al., 2010). We have recently shown evidence for this phenomenon in human melanoma patients (Lakshmikanth et al., 2009). Several studies have also reported various alterations in expression of activating receptors on NK cells from melanoma patients. Decreased expression of receptors like CD161, NKG2D, CD16, NKp30 and NKp46 has been reported (Konjevic et al., 2007). There are also reports on NK cell activity changes between stage I and II melanoma in lymph nodes (Farzad et al., 1990; Hersey et al., 1980), suggesting the involvement of NK cells in the early phase of melanoma development. Sustained exposure of NK cells to NKG2D ligands on the target cell can strongly downregulate the NKG2D receptor as shown in vitro (Benitez et al., 2011) and in vivo using ligand over-expressing transgenic mice (Oppenheim et al., 2005; Wiemann et al., 2005). Furthermore, soluble forms of MICA/B can bind to NKG2D, leading to receptor internalization and escape from NK cell recognition (Groh et al., 2002). A similar phenomenon can occur when tumors overexpress PVR and release it as soluble factor (Baury et al., 2003), which will bind to DNAM-1 and prevent its immune recognition. This could be an effective immune escape mechanism for tumor cells to evade from NK cell surveillance or cytokine-based immunotherapies.

\section{Modulation of inhibition via NK cell receptors}

NK cells and subsets of CTLs express inhibitory receptors specific for non-classical HLA class $\mathrm{Ib}$ molecules with a restricted tissue distribution. Upregulation of HLA-G has been reported in many types of cancer including melanoma, this negatively regulated NK cells and conveyed evasion of NK recognition (Paul et al., 1998). CEACAM-1 (CD66a), a member of the carcinoembryonic antigen family is a cell adhesion molecule, mediating homophilic and heterophilic interations and which can act as an inhibitory NK cell receptor (Markel et al., 2002). CD66a expression in primary tumors of melanoma patients is associated with and can be an independent predictor for risk of metastasis (Thies et al., 2002). Melanoma cells can evade attack from NK cells through CD66a interactions (Markel et al., 2002).

Modulation of costimulation, adhesion or susceptibility to apoptosis

A lack of expression of costimulatory molecules such as B7-1 (CD80), B7-2 (CD86), CD40 and CD70 by tumors hinders an optimal NK activation via CD28 and CD27 costimulatory pathways (Carbone et al., 1997; Galea-Lauri et al., 1999) and may lead to T cell anergy (Schwartz, 1990). The interaction between LFA-1 on NK cells and ICAM-1 (CD54) on tumor cells is important for cell adhesion and killing. Surprisingly, low expression of ICAM-1 by melanoma cells following immunotherapy lead to longer overall survival of patients (Quereux et al., 2007). Shedding of ICAM-1 from melanoma cells has also been described which results in masking of LFA-1 on effector cells (Haass et al., 2005). Melanoma cells can sometimes evade immune recognition from CD8+ T cells and NK cells by developing resistance to TRAIL- and granzyme-B-induced death pathways. In addition, lymphocytes from advanced melanoma patients demonstrated lower expression of TRAIL (Nguyen et al., 2000). Studies of melanoma patients have shown that there is a range of abnormalities that have been selected to inhibit TRAIL-mediated apoptosis (Hersey and Zhang, 2001).

\section{Modulation of NK cell function}

Tumors can influence the nature and efficacy of the immune responses of the host in order to escape immune surveillance. For example, induction of regulatory $\mathrm{T}$ cells (Tregs) or myeloid suppressor cells and/or production of several immunosuppressive factors including arginase-1, NOS-2, IDO, or TGF- $\beta$ by tumor cells or components of the tumor 
microenvironment may result in functional subversion of tumor infiltrating immunocompetent cells (Zitvogel et al., 2006). A recent study showed that tumor cells can induce granzyme B expression in Tregs, which then utilizes this protease to induce the death of NK and CD8+ T cells in a perforin-dependent fashion (Cao et al., 2007). Release of prostaglandin $\mathrm{E} 2\left(\mathrm{PGE}_{2}\right)$ by fibroblasts isolated from metastatic melanoma patients have been shown to interfere with induction of NK cell effector functions (Balsamo et al., 2009).

Immune surveillance of uveal melanoma

Uveal melanoma metastases were shown to frequently lose MHC class I molecules. However, in contrast to cutaneous melanoma where MHC class I loss correlated with worse survival, loss of MHC class I molecules in uveal melanoma lesions was associated with an improved prognosis. This difference may be explained by that uveal melanoma spreads hematogenously, and thereby immune surveillance may be mainly based on NK cells. In contrast, cutaneous melanoma is first spread via lymph nodes resulting in predominant exposure to $\mathrm{T}$ cells (Hanna, 1982; Jager et al., 2002). As noted above, uveal melanoma metastases may escape NK cells via downmodulation of MICA/B proteins. In vitro and in vivo studies of murine melanoma show evidence for NK cell killing of metastatic uveal melanoma in the liver in an IL-2- and TGF- $\beta$-dependent manner (Ma and Niederkorn, 1995). More details on uveal melanoma are discussed in other chapters of this book.

\section{Immunomodulatory agents used to enhance NK cell activity against tumors}

A convergence of information from the fields of molecular biology and cellular immunology has opened new opportunities for immunomodulating agents to be tested in the clinic. We here list some of the immunomodulating agents used to enhance NK cell activity against cancer, tested in vitro and in vivo using cell lines and preclinical mouse models, and some of which are in clinical trials (Fig 2). Other immunotherapeutic agents used against melanoma have been reviewed in the next section.

\subsection{Cytokines}

Many different cytokines are being tested to enhance NK cell activity against tumors. The role of IL-2, IFNs, IL-12, IL-15, IL-18 and IL-21 discretely or in combination with each other or with other modulators has been tested in cancer immunotherapy. Combinations of cytokines have been proposed to enhance NK cytolytic activity (Carson et al., 1994).

IL-2 comprises a cornerstone of systemic therapeutic modalities in disseminated melanoma (Tsao et al., 2004). IL-2 has been used to generate in vitro Lymphokine Activated Killer (LAK) cells, consisting of activated NK cells and T cells. Adoptive infusion of LAK cells is reviewed in section 6.1. Clinical trials have assessed effects of low-dose IL-2 administration on activation of NK cells in cancer patients. Whereas IL-2 significantly expanded the circulating NK cells in vivo, cytotoxicity was increased to some extent, as determined by in vitro assays (Miller et al., 1997). Infusion of IL-2-activated NK cell-enriched populations or intravenous IL-2 infusions combined with subcutaneous IL-2 augmented in vivo NK cell function but without consistent efficacy when compared with matched control cohorts (L. J. Burns et al., 2003). Objective clinical benefits were observed only in $20 \%$ of patients treated with IL-2, occasionally patients were cured. Immunocomplexing of cytokine and anticytokine monoclonal antibody $(\mathrm{mAb})$ prolongs half-life and can increase or modify cytokine 
activities in vivo. Treatment with IL-2 immunocomplexes, lead to suppression of B16 tumor metastases in the lung (Jin et al., 2008). Hence, IL-2 immunocomplex treatment offers a novel therapeutic strategy to enhance NK cell activities also in humans. However, there are doselimiting toxicities associated with IL-2, which have compromised its clinical use and other cytokines with an improved therapeutic index are therefore needed.

IFNs are a group of cytokines mainly known for their antiviral effect. They have a wide range of activities in modulating the immune system and have been reported effective in mice against spontaneous as well as experimental metastases (IFN- $\alpha$ ) (Brunda et al., 1984). IFN- $\alpha$ enhances innate immune antitumor activity by inducing NK cell proliferation and cytotoxicity (Konjevic et al., 2007) and induces a favorable Th1-response (Bremers and Parmiani, 2000). IFN- $\alpha$ induces cytokines, perforin and FasL and mediates antitumor activity via interferon response factor-1 (IRF-1) (Kroger et al., 2002). It also promotes an increase in NKG2D and CD161 expression on NK cells in melanoma patients (Konjevic et al., 2010). IFN- $\alpha$ is currently approved as adjuvant therapy in high-risk melanoma patients, to eradicate micrometastases after surgical removal of the primary tumor and has demonstrated improved disease free survival but with conflicting results regarding overall survival (Ascierto and Kirkwood, 2008). Combination treatment with IFN- $\alpha$ and IL-2 induced expression of activating receptors on NK cells and was found to be clinically beneficial in melanoma patients (Konjevic et al., 2010). Upregulation of MHC class I expression is a major effect of IFN- $\gamma$, which may induce resistance to NK cells. Data on the effects of IFN- $\gamma$ on tumor cell killing by NK cells have however been conflicting (Routes, 1992). The current notion on IFN- $\gamma$ is that it can be pro-tumorigenic and anti-tumorigenic, depending on the context, intensity and durability of the IFN- $\gamma$ signal (Zaidi et al., 2011). The IFN 'survival signature' is one of the mechanisms to evade immunosurveillance. Therefore IFN- $\gamma /$ IFN- $\gamma$-R or their downstream pathway members represent potential prognostic markers in melanoma.

IL-12 acts as an NK cell and T cell growth factor (Perussia et al., 1992), enhances cytolytic activity of NK and LAK cells (Naume et al., 1992), and augments cytolytic T cell responses (Gately et al., 1992). IL-12 has direct effects on lymphocytes and NK cells by enhancing IFN$\gamma$ production (Lamont and Adorini, 1996). In a mouse melanoma model, intratumoral treatment with IL-12-encoding DNA resulted in NK cell-mediated significant regression in melanoma tumor development (Heinzerling et al., 2002). NK cells co-injected with IL-2 and IL-12 into SCID mice showed favorable antitumor effects (Hill et al., 1994). The interaction between IL-2 and IL-12 was found to enhance NK cell spontaneous cytotoxicity against tumor cells (Chehimi et al., 1992). In addition it stimulates NK cell cytokine production that may induce antitumor activity from macrophages and neutrophils (Perussia et al., 1992). The combination of IL-12 and Trastuzumab (Herceptin) in a mouse model led to tumor regression mediated through NK cell IFN- $\gamma$ production (Jaime-Ramirez et al., 2011). HER2 is the target structure for the mAb Trastuzumab and its overexpression is associated with a poor prognosis (Ross and Fletcher, 1998). IL-12 in combination with stimulation of the TNF receptor superfamily member $4-1 \mathrm{BB}$ has been suggested to stimulate CD8+ T-cell responses in a mouse melanoma model. Hence a synergy between IL-12 and anti-4-1BB induced regression of established melanoma via NK and CD8+ T cells (Xu et al., 2004). Adenovirusvector-mediated delivery of IL-12 was shown to improve efficacy of adenovirus-vectormediated immunization with a melanoma antigen in a mouse B16 melanoma metastasis model. The effects of this combined therapy depended on both T cell-mediated immunity and NK cell-mediated cytotoxicity (Hirschowitz and Crystal, 1999). 
IL-15 is involved in development and maintenance of NK cells and binds partly to the same receptor as IL-2 (Fehniger and Caligiuri, 2001). IL-15 overexpression in transgenic mice enhanced antitumor immunity (Yajima et al., 2002). A pronounced synergy between IL-15 and IL-12 that exceeds the IL-2 and IL-15 combination has been reported (Seidel et al., 1998). IL-15 is as efficacious as IL-2 but may have a superior therapeutic index (Munger et al., 1995). Clinical trials of IL-15 are expected soon (Fewkes and Mackall, 2010).

IL-18 is similar to IL-12 in inducing IFN- $\gamma$ secretion from NK and T cells and augments NK cytolytic activity (Okamura et al., 1995). Although IL-18 and IL-12 synergize in IFN- $\gamma$ production, their receptors and signal-transduction pathways appear to be different (Kohno et al., 1997). Evaluation of IL-18+IL-12 in a mouse melanoma model showed synergistic antitumor effects that associated with markedly elevated IFN- $\gamma$ production but also had side effects. The IL-18 effect was mediated by NK cells and CD4+ T cells, independent of IFN- $\gamma$ and IL-12 (Osaki et al., 1998). A phase II study of IL-18 in patients with metastatic melanoma has confirmed its safety but suggested limited efficacy of IL-18 monotherapy in this setting. IL-18 may be of better use in combination with other immunostimulatory cytokines, vaccines, or monoclonal antibodies (Srivastava et al., 2010).

IL-21 is produced by CD4+ T cells, have sequence homology to IL-2, IL-4, and IL-15 and stimulate T and NK cells. Synergy between IL-21, FLT3 ligand and IL-15, promotes expansion and differentiation of NK cells from the bone marrow and enhances their lytic function against B16 melanoma targets in vitro (Parrish-Novak et al., 2000). Administration of plasmid DNA encoding murine IL-21 significantly induced tumor killing by NK cells in vivo without obvious toxicity and prolonged survival of s.c tumor bearing mice (G. Wang et al., 2003). Clinical trials have been initiated, showing that IL-21 is well tolerated and possesses antitumor effects when administered as a single agent to patients with malignant melanoma and renal cell carcinoma. Future studies may combine IL-21 with vaccines and adoptive cell therapies (Fewkes and Mackall, 2010).

\subsection{Chemotherapeutic agents}

This section will focus on chemotherapeutic agents with immunomodulatory function on NK cells. The epidermal growth factor receptor (EGFR) pathway inhibitors, erlotinib and gefitinib, induce NKG2D ligands on cancer cells and sensitize them to NK cell-mediated killing as demonstrated in lung cancer (Kim et al., 2011). The small molecule multiple protein kinase inhibitors, sorafenib and sunitinib, have been approved for treatment of renal cell carcinoma. Sorafenib and sunitinib upregulate NKG2D ligands as observed on nasopharyngeal carcinoma (Huang et al., 2011). Sorafenib also inhibits the shedding of MICA on hepatocellular carcinoma (Kohga et al., 2010). The ubiquitin-proteasome pathway inhibitor bortezomib was shown to sensitize tumors to autologous NK cytotoxicity and this effect was enhanced upon depletion of Tregs (Lundqvist et al., 2009), as will be further discussed in section 7. Therapeutic compounds like thalidomide (Davies et al., 2001) in multiple myeloma and imatinib in gastrointestinal stromal tumors (Borg et al., 2004) might indirectly enhance NK cell functions, survival and proliferation (Fig 2). MICA and MICB proteins may be induced on hepatoma cells with an increase in NK cellmediated lysis, using the histone deacetylase (HDAC) inhibitor, Valproic acid (Armeanu et al., 2005). 


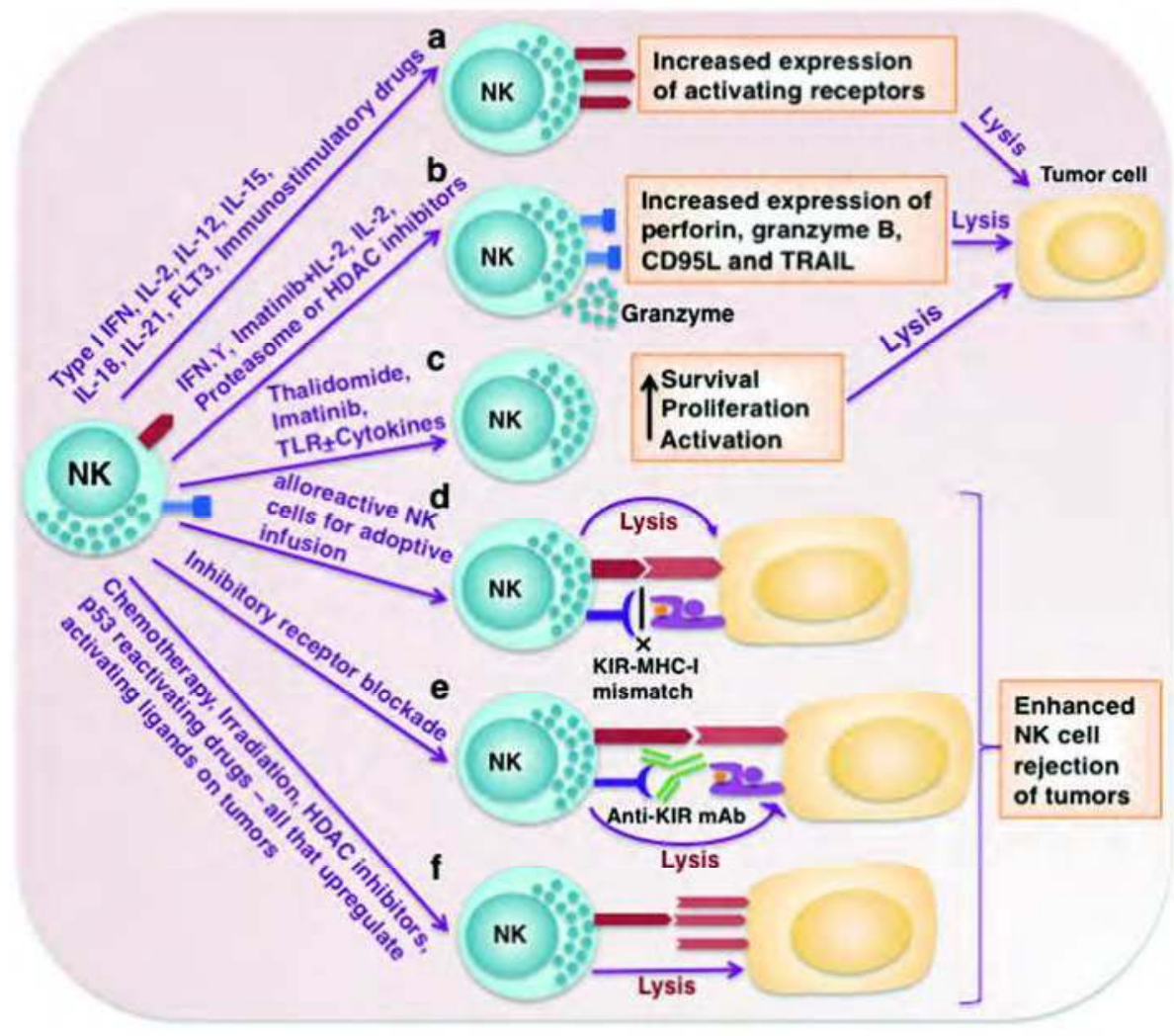

Fig. 2. Immunomodulatory strategies to harness NK cells in melanoma.

\subsection{Blockade of inhibitory NK cell receptors}

NK cell missing-self-reactivity (as alluded to in section 2.2) can be mimicked by blocking interaction between inhibitory receptors on NK cells and cognate MHC class I ligands. Blocking of inhibitory receptors using $\mathrm{F}\left(\mathrm{ab}^{\prime}\right)_{2}$ fragments enhanced anti-tumor activity both in vitro and in vivo and inhibited growth of syngeneic leukemia cells in an NK celldependent manner (Koh et al., 2001). However, it was not clear whether the in vivo effect occurred through direct induction of NK cell rejection or long-term influence on the NK cell population. Using a mouse model, we investigated this further using $\mathrm{F}\left(\mathrm{ab}^{\prime}\right)_{2}$ fragments to block Ly49C/I NK cell inhibitory receptors on mouse NK cells. When used alone, inhibitory receptor blockade lead to enhanced rejection of RMA lymphoma cells. In combination with high-dose IL-2 it further boosted the anti-lymphoma activity of NK cells. Combination therapy even delayed growth of B16 melanoma tumors established s.c (Vahlne et al., 2010) (Fig 2). Recently, Romagne et al have generated and characterized a fully human anti-KIR therapeutic candidate mAb, 1-7F9, which is currently in clinical development with the overall aim to increase antitumor responses of endogenous NK cells in patients with hematological malignancies without transplantation (Romagne et al., 2009), this therapy was not tested with solid tumors yet. 


\section{Immunological aspects of melanoma and its immunotherapy}

Melanoma is an immunogenic tumor resistant to chemotherapy and irradiation. Though there is some evidence that metastatic melanoma can be successfully treated by immunotherapy only in a minority of patients (Rosenberg, 1997), recent advances have highlighted the potential of immunotherapeutic approaches as a valuable complement for cancer therapy (Dudley et al., 2002). While chemotherapy treats the tumor directly, immunotherapy treats the immune system. Finding the right formulation of combination therapies, determining the optimal dose and schedule of administration is the main challenge for incorporating immunotherapies into the standard of care. As tumors evade $\mathrm{T}$ cell recognition, they become prone to NK cell attack. NK cell numbers in tumors increase following activation in vivo (Albertsson et al., 2003) or after adoptive transfer (Geller et al., 2011). Further, NK cells detected in melanomas after isolation of TILs, were more potent tumor killers than T cells (Azogui et al., 1991). Previously reported correlations between histological features and NK activity suggest that NK cells may represent an additional prognostic factor (Hersey et al., 1982). The detection of NK cells in stage IV melanomas (Fregni et al., 2011) further encourages us to design NK-based immunotherapeutic strategies for melanoma patients. As many melanoma patients are of old age it is important to consider age-dependent changes in the immune system in relation to immunotherapy of melanoma. Information on responses to immunotherapy in elderly is sparse, but in one study, high dose IL-2 treatment of tumor patients, aged 70 or older, resulted in a response rate similar to that in younger patients (Quan et al., 2005).

\subsection{Adoptive NK cell therapy}

NK cells are attractive for adoptive cell therapy because of their unique ability to lyse target cells without any priming. Moreover, the reported low MHC class I expression on melanoma metastases (Algarra et al., 1997) allows NK cell triggering. Adoptive transfer of immune cells to patients with cancer was pioneered in the mid-1980s by Rosenberg and collaborators who infused autologous LAK cells together with high-doses of IL-2 to patients with advanced metastatic melanoma and renal cell carcinoma (Rosenberg et al., 1985). The FDA approved this treatment for patients with melanoma metastases (Rosenberg et al., 1987) with $20 \%$ of patients responding to the LAK cell infusion containing autologous NK cells. In follow up studies there was a response rate of $13-17 \%$ of the patients. The limited success may be explained by that high doses of IL-2 expand regulatory T cells, inhibiting NK cell activity via TGF- $\beta$ (Ghiringhelli et al., 2005). The modest results of LAK cell/IL-2 therapy were further limited by serious side effects. A new era in the exploitation of NK cells in cancer immunotherapy started with Ruggeri et al who demonstrated that in bone marrow transplanted patients with a donor-KIR/host-KIR-ligand mismatch, alloreactive donor-derived NK cells were protective against acute myeloid leukemia (AML) relapse (Ruggeri et al., 2002). This study has been reproduced in AML patients by Giebel S et al (Giebel et al., 2003). Furthermore, alloreactive KIR-incompatible NK cells effectively eliminate melanoma and renal cancer cells in vitro (Igarashi et al., 2004). These data would suggest that allogeneic NK cells may have potent antitumor effects but this strategy remains to be tested in melanoma patients. A potential problem with adoptive transfer of NK cells is to direct the NK cells to the site of the tumor. Even if adoptively transferred NK cells produce cytokines like IFN- $\gamma$ and TNF- $\alpha$ that may be able to function systemically, these cells need to be in close contact with the tumor for recognition and complete elimination of 
tumor targets. Activation of NK cells with IL-2 ex vivo increased their migration to the tumor site, and in vivo cytokine treatment may improve this further (Yang et al., 2003).

\subsection{Combinatorial therapies}

Immunological and biological agents convey their antitumor effect by potentiating cytotoxic and anti-proliferative effects of chemotherapy by modulating antitumor reactions mediated primarily by cell subpopulations of the innate immunity. The range of therapeutic options against melanoma encompasses chemotherapeutic, immune, anti-angiogenic and hormonal strategies. The sequence of these therapies used should correlate with the therapeutic activity. One study demonstrated that a subcutaneous metastasis obtained after two rounds of therapy with fotemustine, IFN- $\alpha$ and IL-2 showed strong expression of MICA/B on tumor cells and NKG2D on the infiltrating immune cells, while metastases from the same patient prior to therapy lacked these molecules. So chemotherapy may offer a great alternative in the induction of activating ligands on tumors (Vetter et al., 2004).

\section{Strategies and current opportunities for NK cell-based immunotherapy of melanoma}

The challenges faced by clinicians and the scientific community working with melanoma are formidable and it is required that we translate the growing body of scientific information clinically to be useful in targeting melanoma in patients and prolonging their survival. $\mathrm{T}$ cell-based immunotherapies have shown limited success so far (Fang et al., 2008). The main obstacle in using adoptive cell therapy with T cells is MHC class I-negative tumor variants that are insensitive to T cells (R. F. Wang and Rosenberg, 1996). Further, a cancer vaccine based solely on $\mathrm{T}$ cell therapy might drive development of class I-negative melanoma variants and/or variants that have lost the immunodominant target antigen (Yee et al., 2002). Therefore, new strategies are required. Reduced MHC class I expression opens up opportunities for NK cell-based immunotherapy at early stages of the disease when ligands for NK receptors are first expressed. Based on findings obtained on immunomodulation of NK cells we put forth our opinion on promising strategies and opportunities that can be explored for NK cell-based immunotherapy of melanoma.

Over the past years, there have been several reports on the importance of NK cells in immunotherapy (Fernandez et al., 1999). As the knowledge on NK cells has been growing over the last two decades, successful NK-based therapeutic breakthroughs have however not been accomplished. One potential reason for failure of adoptively transferred autologous NK cells or LAKs to mediate objective rejection of metastatic solid tumors is that autologous NK cells are subject to inhibition via KIR-ligands on tumor cells (Law et al., 1995). In addition, autologous NK cells in melanoma often have decreased expression of stimulating NK cell receptors. KIR/KIR-ligand mismatched NK cells have shown enhanced efficacy against melanoma and renal cell carcinoma in vitro (Igarashi et al., 2004). Thus, allogeneic NK cells may have a greater anti-tumor effect than autologous ones in adoptive transfer (Ljunggren and Malmberg, 2007; Terme et al., 2008). In a promising study by Miller et al, human allogeneic NK cells derived from haploidentical related donors were adoptively transferred along with IL-2 in the presence of high-dose cyclophosphamide and fludarabine immunosuppression. NK cells expanded and persisted in vivo accompanied by a rise in endogenous IL-15 levels (Miller et al., 2005). This lead to an enhanced antitumor effect, which was prevalent when KIR/KIR-ligand mismatch existed between donor and 
recipient, reminiscent of results in AML patients receiving haploidentical hematopoietic transplantation. Further, 'unlicensed' or 'hyporesponsive' NK cells, i.e. NK cells expressing no inhibitory receptors for self-HLA class I, lysed melanoma cells in vitro (Carrega et al., 2009). Appropriate activation may enable these NK cells to kill autologous melanomas. These cells can act independently of HLA class I expression in melanoma cells, but more studies are needed to understand their functional properties and trafficking patterns to utilize them successfully in cancer immunotherapeutic approaches. Clinical trials using adoptive transfer of NK cells are currently ongoing (Velardi et al., 2009).

Recently, a new strategy was proposed by Markel et al to augment anticancer activity by NK cells based on matching of activating NK cell receptors and their ligands. Increased killing was observed against melanomas in vitro in matched effector-target combinations (Markel et al., 2009). Matching of activating receptors/ligands as well as ex vivo testing of tumor susceptibility to lysis by NK cells (Carlsten et al., 2007) may improve adoptive cell therapy protocols.

Most clinical studies exploiting allogeneic NK cells for adoptive immunotherapy have been performed with NK cells selected from leukapheresis products by immunomagnetic bead selection protocol (Iyengar et al., 2003; Meyer-Monard et al., 2009). Ex vivo expansions of NK cells will facilitate infusion of higher numbers of activated NK cells (Carlens et al., 2001). Several approaches are being tested. Large-scale expansion of functional human NK cells from hematopoietic progenitor and stem cells without use of animal products and feeder cells (cytokine-based method) generated 100\% pure and activated NK cells at a high logscale magnitude which were able to lyse AMLs and solid tumors like melanoma (Spanholtz et al., 2010). This method may hold a great promise for ex vivo generation of clinical grade NK cell products for cellular immunotherapy against melanoma.

Tumors can be sensitized to NK cell killing via death receptors. Bortezomib treatment of B16 melanoma has been shown to augment their susceptibility to syngeneic NK cells in mice by increasing TRAIL receptors on tumor cells, as growth of Bortezomib treated human melanomas was delayed in SCID mice adoptively transferred with human NK cells (Lundqvist et al., 2009). Hence, NK cell activity against cancer can be substantially bolstered by combining adoptive NK infusions with bortezomib treatment (Lundqvist et al., 2006). Other therapeutic approaches used to activate the TRAIL-system are reviewed by Hersey (Hersey and Zhang, 2001).

As elucidated in the previous sections, we have recently demonstrated that NK cells have the intrinsic capacity to recognize and target malignant melanoma cells. Tumor metastases in the lymph nodes were more susceptible to peripheral blood NK cells. NCRs and DNAM1, but not NKG2D, emerged as key receptors in NK cell-melanoma cytotoxicity, indicating that NK subsets expressing these receptors might be good candidates for adoptive transfer in melanoma patients. Furthermore, using a xenogeneic model of cell therapy we have shown that allogeneic NK cells potently eliminated LN metastases expressing ligands for NCRs and DNAM-1, but did not affect metastases from skin, ascites, or pleura (Lakshmikanth et al., 2009). The use of allogeneic NK cells in therapy of melanoma patients needs to be further tested (Fig 3) but the results suggest enhanced potency of KIRmismatched allogeneic NK cells against melanoma cells (Igarashi et al., 2004) and provides important implications for the use of NK cell immunotherapy in melanoma. Based on the findings obtained in our study, we have presented our perspectives as two non-exclusive approaches that include augmentation of endogenous NK cell activation/migration pathways and intervention with allogeneic NK cell therapy. We have also raised a number of unanswered questions whose knowledge will help better in designing the most effective 
therapy for melanoma (Burke et al., 2010). It is understood that once the melanoma tumor spreads beyond the skin and regional lymph nodes, it is frequently incurable by available chemotherapeutic agents. Since tumor metastases from lymph nodes were more susceptible to NK cells it may be crucial to recruit NK cells and elicit response in that site to prevent hematogenous tumor dissemination and further metastasis development. Autologous peripheral blood NK cells could be redirected to the LN by administration of TLR ligands as shown in a mouse model (Martin-Fontecha et al., 2004). It is of note that most of the TLR ligands can serve as excellent adjuvants in classical $\mathrm{T}$ cell vaccines. It has been shown that only a small proportion of advanced melanoma patients respond to IL-2. However, it is still one of the few cytokine therapies with demonstrable clinical activities. Recent data from a mouse model suggest that NK-tumor cell interaction via DNAM-1 or NKG2D receptors was important for the efficacy of IL-2, -12 or -21 therapy (Chan et al., 2010). Hence assessment of ligand expression on tumors may be a predictive marker for the efficacy of cytokine therapy (Fig 3). Further, in light of our results, augmenting DNAM-1-mediated recognition of melanoma appears as an attractive approach. Recently, Santoni and coworkers found that melphalan, doxorubicin and bortezomib increase DNAM-1 ligands on multiple myeloma cell surface, similar immuno-chemotherapy could optimize melanoma patients' treatment leading to a more effective autologous NK cell anti-melanoma cytotoxicity (Soriani et al., 2009). Furthermore, genotoxic chemotherapeutic agents have been shown to upregulate NK activating ligands for NKG2D like MICA/B on tumor cells by mechanisms that activate the Hsp70 promoter (Liu et al., 1996). This is of particular interest as it would link chemotherapy and immunotherapy and explains the synergistic effects of these different therapeutic approaches observed clinically. Similarly, chemotherapeutic agents that activate p53 can also induce NK specific activating ligands on tumors and augment NK cellmediated killing of melanomas and other tumor cell types as shown by us in a more recent study ( $\mathrm{Li}$ et al., manuscript submitted, 2011). Thus, re-establishing NK cell immunosurveillance by strategically forcing the expression of NK activating ligands on tumor cells by appropriate chemotherapeutic antiblastic drugs can be an interesting approach for melanoma therapy (Fig 3).

As mentioned in previous sections, we have recently shown that NK cell missing-selfreactivity can be mimicked by blocking self-specific inhibitory receptors on NK cells using $\mathrm{F}\left(\mathrm{ab}^{\prime}\right)_{2}$ fragments which in combination with IL-2 lead to delayed outgrowth of melanoma tumor cells (Vahlne et al., 2010). Further, Romagne et al have characterized a fully human anti-KIR therapeutic candidate mAb, which is currently in clinical development, with the overall aim to boost antitumor responses of endogenous NK cells from patients with hematological malignancies without transplantation (Romagne et al., 2009). This needs to be tested in solid tumors like melanoma as they do express a certain level of MHC class I molecules on their cell surface during the initial stages of their metastatic spread. Hence, NK-based therapeutic strategies in combination with each other, as well as with established treatments, could form the basis for future therapy developments in melanoma.

\section{Conclusion}

As advances made in tumor immunology are enabling fast-paced discovery and translation of results into potential clinical tools, there is clearly a dire need to improve response rates and overall survival of melanoma patients. Despite limitations in the NK cell field, a great interest has grown recently in exploiting the potential of NK cell-based immunotherapy 


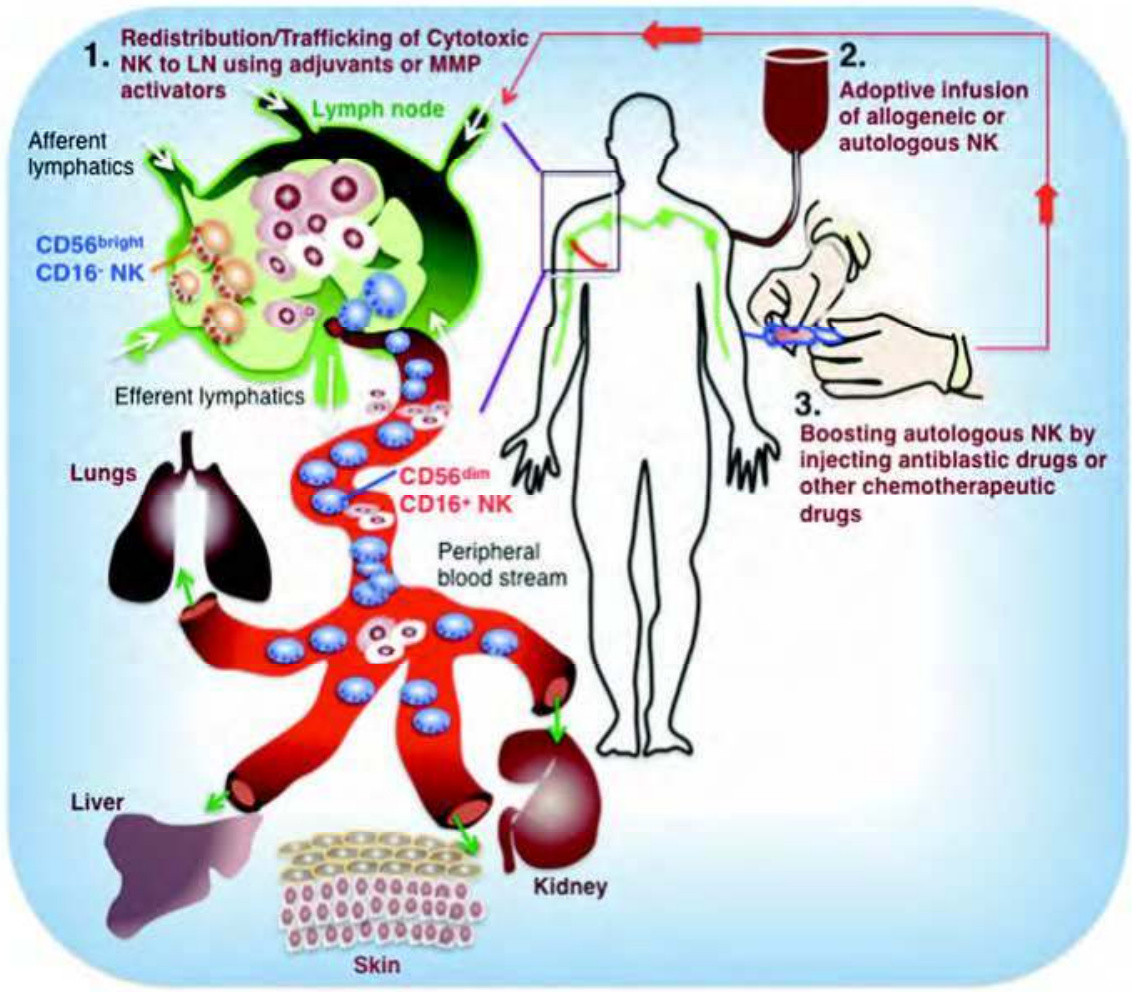

Fig. 3. Strategies to manipulate NK cells in targeting melanoma. 1). The subset of NK cells residing in the blood are CD56 dim CD16+, a more cytotoxic subset unlike the CD56 bright CD16- subset that resides in the lymph node which has a more cytokine secreting profile. Peripheral blood NK cells can be redistributed or trafficked into the LN by using TLR adjuvants or matrix metalloprotease (MMP) activators; 2) Adoptive transfer of higher numbers of autologous NK or allogeneic NK cells from healthy donors that can target metastases in LN which prevent further hematogenous spread of tumors into the viscera; 3 ) Boosting autologous NK cells by injecting antiblastic drugs like doxorubicin, bortezomib or melphalan, that might upregulate ligands for NKG2D or DNAM-1 on tumors.

(Long et al., 2001) as shown by in vitro studies (Igarashi et al., 2004), murine studies (Lundqvist et al., 2007), retrospective data from allogeneic transplant trials (Giebel et al., 2003; Ruggeri et al., 2007), and clinical trials evaluating adoptive allogeneic NK cell infusions in cancer patients (Miller et al., 2005). Clearly, many questions have to be answered before designing optimal NK-based therapy. Great achievements have been made at the bench and in the clinic over the last decade that will gain cancer patients in the coming future. Several prognostic markers have also been determined. Furthermore, by the use of comprehensive genomic, genetic and phenotypic analysis of human samples and with refined mouse models, molecular insights into the mechanisms of resistance of melanoma tumors to various immune-based therapies or chemotherapeutic drugs will be understood well. It is reasonable to anticipate that alternative therapeutics to resistant tumors and 
various combination strategies will emerge in the coming future. Development of effective therapeutic regimens against advanced melanoma will require more sustained effort and the hope is that the developments in understanding of melanoma tumor biology will translate into a significant benefit for patients.

\section{Acknowledgement}

We would like to thank Klas Kärre for critical reading of the manuscript and for providing thoughtful comments. This work was supported by grants from Karolinska Institutet, the Åke Wiberg foundation, the Magnus Bergwall foundation, the Royal Swedish Academy of Sciences, the Swedish National Board of Health and Welfare, 'Syskonen Svensssons fond' and Novo Nordisk A/S to M.H.J; Postdoctoral Research grants from Karolinska Institutet and The Swedish Research Council (524-2009-846) to T.L.K.

\section{References}

Albertsson, P.A., Basse, P.H., Hokland, M., Goldfarb, R.H., Nagelkerke, J.F., Nannmark, U., and Kuppen, P.J. (2003). NK cells and the tumour microenvironment: implications for NK-cell function and anti-tumour activity. Trends Immunol, 24, 11, 603-609.

Algarra, I., Collado, A., and Garrido, F. (1997). Altered MHC class I antigens in tumors. Int J Clin Lab Res, 27, 2, 95-102.

Armeanu, S., Bitzer, M., Lauer, U.M., Venturelli, S., Pathil, A., Krusch, M., Kaiser, S., Jobst, J., Smirnow, I., Wagner, A., Steinle, A., and Salih, H.R. (2005). Natural killer cellmediated lysis of hepatoma cells via specific induction of NKG2D ligands by the histone deacetylase inhibitor sodium valproate. Cancer Res, 65, 14, 6321-6329.

Armstrong, B.K., and Kricker, A. (2001). The epidemiology of UV induced skin cancer. J Photochem Photobiol B, 63, 1-3, 8-18.

Ascierto, P.A., and Kirkwood, J.M. (2008). Adjuvant therapy of melanoma with interferon: lessons of the past decade. J Transl Med, 6, 62 .

Azogui, O., Avril, M.F., Margulis, A., Guillard, M., Caillou, B., and Prade, M. (1991). Tumorinfiltrating CD3- NK cells are more effective than CD3+ T cells in killing autologous melanoma cells. J Invest Dermatol, 97, 3, 425-429.

Balsamo, M., Scordamaglia, F., Pietra, G., Manzini, C., Cantoni, C., Boitano, M., Queirolo, P., Vermi, W., Facchetti, F., Moretta, A., Moretta, L., Mingari, M.C., and Vitale, M. (2009). Melanoma-associated fibroblasts modulate NK cell phenotype and antitumor cytotoxicity. Proc Natl Acad Sci U S A, 106, 49, 20847-20852.

Baury, B., Masson, D., McDermott, B.M., Jr., Jarry, A., Blottiere, H.M., Blanchardie, P., Laboisse, C.L., Lustenberger, P., Racaniello, V.R., and Denis, M.G. (2003). Identification of secreted CD155 isoforms. Biochem Biophys Res Commun, 309, 1, 175182.

Becker, J.C., Vetter, C.S., Schrama, D., Brocker, E.B., and thor Straten, P. (2000). Differential expression of CD28 and CD94/NKG2 on T cells with identical TCR beta variable regions in primary melanoma and sentinel lymph node. Eur J Immunol, 30, 12, 36993706.

Benitez, A.C., Dai, Z., Mann, H.H., Reeves, R.S., Margineantu, D.H., Gooley, T.A., Groh, V., and Spies, T. (2011). Expression, signaling proficiency, and stimulatory function of 
the NKG2D lymphocyte receptor in human cancer cells. Proc Natl Acad Sci U S A, $108,10,4081-4086$.

Biron, C.A., Nguyen, K.B., Pien, G.C., Cousens, L.P., and Salazar-Mather, T.P. (1999). Natural killer cells in antiviral defense: function and regulation by innate cytokines. Annu Rev Immunol, 17, 189-220.

Borg, C., Terme, M., Taieb, J., Menard, C., Flament, C., Robert, C., Maruyama, K., Wakasugi, H., Angevin, E., Thielemans, K., Le Cesne, A., Chung-Scott, V., Lazar, V., Tchou, I., Crepineau, F., Lemoine, F., Bernard, J., Fletcher, J.A., Turhan, A., Blay, J.Y., Spatz, A., Emile, J.F., Heinrich, M.C., Mecheri, S., Tursz, T., and Zitvogel, L. (2004). Novel mode of action of c-kit tyrosine kinase inhibitors leading to NK cell-dependent antitumor effects. J Clin Invest, 114, 3, 379-388.

Bottino, C., Castriconi, R., Pende, D., Rivera, P., Nanni, M., Carnemolla, B., Cantoni, C., Grassi, J., Marcenaro, S., Reymond, N., Vitale, M., Moretta, L., Lopez, M., and Moretta, A. (2003). Identification of PVR (CD155) and Nectin-2 (CD112) as cell surface ligands for the human DNAM-1 (CD226) activating molecule. J Exp Med, $198,4,557-567$.

Bremers, A.J., and Parmiani, G. (2000). Immunology and immunotherapy of human cancer: present concepts and clinical developments. Crit Rev Oncol Hematol, 34, 1, 1-25.

Brunda, M.J., Rosenbaum, D., and Stern, L. (1984). Inhibition of experimentally-induced murine metastases by recombinant alpha interferon: correlation between the modulatory effect of interferon treatment on natural killer cell activity and inhibition of metastases. Int J Cancer, 34, 3, 421-426.

Bryceson, Y.T., March, M.E., Barber, D.F., Ljunggren, H.G., and Long, E.O. (2005). Cytolytic granule polarization and degranulation controlled by different receptors in resting NK cells. J Exp Med, 202, 7, 1001-1012.

Bryceson, Y.T., March, M.E., Ljunggren, H.G., and Long, E.O. (2006). Activation, coactivation, and costimulation of resting human natural killer cells. Immunol Rev, 214, 73-91.

Burke, S., Lakshmikanth, T., Colucci, F., and Carbone, E. (2010). New views on natural killer cell-based immunotherapy for melanoma treatment. Trends Immunol, 31, 9, 339-345.

Burns, E.A., and Leventhal, E.A. (2000). Aging, immunity, and cancer. Cancer Control, 7, 6, 513-522.

Burns, L.J., Weisdorf, D.J., DeFor, T.E., Vesole, D.H., Repka, T.L., Blazar, B.R., Burger, S.R., Panoskaltsis-Mortari, A., Keever-Taylor, C.A., Zhang, M.J., and Miller, J.S. (2003). IL-2-based immunotherapy after autologous transplantation for lymphoma and breast cancer induces immune activation and cytokine release: a phase I/II trial. Bone Marrow Transplant, 32, 2, 177-186.

Cao, X., Cai, S.F., Fehniger, T.A., Song, J., Collins, L.I., Piwnica-Worms, D.R., and Ley, T.J. (2007). Granzyme B and perforin are important for regulatory T cell-mediated suppression of tumor clearance. Immunity, 27, 4, 635-646.

Carbone, E., Ruggiero, G., Terrazzano, G., Palomba, C., Manzo, C., Fontana, S., Spits, H., Karre, K., and Zappacosta, S. (1997). A new mechanism of NK cell cytotoxicity activation: the CD40-CD40 ligand interaction. J Exp Med, 185, 12, 2053-2060.

Carlens, S., Gilljam, M., Chambers, B.J., Aschan, J., Guven, H., Ljunggren, H.G., Christensson, B., and Dilber, M.S. (2001). A new method for in vitro expansion of cytotoxic human CD3-CD56+ natural killer cells. Hum Immunol, 62, 10, 1092-1098. 
Carlsten, M., Bjorkstrom, N.K., Norell, H., Bryceson, Y., van Hall, T., Baumann, B.C., Hanson, M., Schedvins, K., Kiessling, R., Ljunggren, H.G., and Malmberg, K.J. (2007). DNAX accessory molecule-1 mediated recognition of freshly isolated ovarian carcinoma by resting natural killer cells. Cancer Res, 67, 3, 1317-1325.

Carrega, P., Pezzino, G., Queirolo, P., Bonaccorsi, I., Falco, M., Vita, G., Pende, D., Misefari, A., Moretta, A., Mingari, M.C., Moretta, L., and Ferlazzo, G. (2009). Susceptibility of human melanoma cells to autologous natural killer (NK) cell killing: HLA-related effector mechanisms and role of unlicensed NK cells. PLoS One, 4, 12, e8132.

Carson, W.E., Giri, J.G., Lindemann, M.J., Linett, M.L., Ahdieh, M., Paxton, R., Anderson, D., Eisenmann, J., Grabstein, K., and Caligiuri, M.A. (1994). Interleukin (IL) 15 is a novel cytokine that activates human natural killer cells via components of the IL-2 receptor. J Exp Med, 180, 4, 1395-1403.

Casado, J.G., Pawelec, G., Morgado, S., Sanchez-Correa, B., Delgado, E., Gayoso, I., Duran, E., Solana, R., and Tarazona, R. (2009). Expression of adhesion molecules and ligands for activating and costimulatory receptors involved in cell-mediated cytotoxicity in a large panel of human melanoma cell lines. Cancer Immunol Immunother, 58, 9, 1517-1526.

Chan, C.J., Andrews, D.M., McLaughlin, N.M., Yagita, H., Gilfillan, S., Colonna, M., and Smyth, M.J. (2010). DNAM-1/CD155 interactions promote cytokine and NK cellmediated suppression of poorly immunogenic melanoma metastases. J Immunol, 184, 2, 902-911.

Chehimi, J., Starr, S.E., Frank, I., Rengaraju, M., Jackson, S.J., Llanes, C., Kobayashi, M., Perussia, B., Young, D., Nickbarg, E., and et al. (1992). Natural killer (NK) cell stimulatory factor increases the cytotoxic activity of NK cells from both healthy donors and human immunodeficiency virus-infected patients. J Exp Med, 175, 3, 789-796.

Chin, L., Garraway, L.A., and Fisher, D.E. (2006). Malignant melanoma: genetics and therapeutics in the genomic era. Genes Dev, 20, 16, 2149-2182.

Cochran, A.J., Huang, R.R., Lee, J., Itakura, E., Leong, S.P., and Essner, R. (2006). Tumourinduced immune modulation of sentinel lymph nodes. Nat Rev Immunol, 6, 9, 659670.

Cochran, A.J., Morton, D.L., Stern, S., Lana, A.M., Essner, R., and Wen, D.R. (2001). Sentinel lymph nodes show profound downregulation of antigen-presenting cells of the paracortex: implications for tumor biology and treatment. Mod Pathol, 14, 6, 604608.

Colucci, F., Caligiuri, M.A., and Di Santo, J.P. (2003). What does it take to make a natural killer? Nat Rev Immunol, 3, 5, 413-425.

Cooper, M.A., Fehniger, T.A., and Caligiuri, M.A. (2001). The biology of human natural killer-cell subsets. Trends Immunol, 22, 11, 633-640.

Davies, F.E., Raje, N., Hideshima, T., Lentzsch, S., Young, G., Tai, Y.T., Lin, B., Podar, K., Gupta, D., Chauhan, D., Treon, S.P., Richardson, P.G., Schlossman, R.L., Morgan, G.J., Muller, G.W., Stirling, D.I., and Anderson, K.C. (2001). Thalidomide and immunomodulatory derivatives augment natural killer cell cytotoxicity in multiple myeloma. Blood, 98, 1, 210-216.

Davis, D.M., and Dustin, M.L. (2004). What is the importance of the immunological synapse? Trends Immunol, 25, 6, 323-327. 
Diefenbach, A., Jensen, E.R., Jamieson, A.M., and Raulet, D.H. (2001). Rae1 and H60 ligands of the NKG2D receptor stimulate tumour immunity. Nature, 413, 6852, 165-171.

Dudley, M.E., Wunderlich, J.R., Robbins, P.F., Yang, J.C., Hwu, P., Schwartzentruber, D.J., Topalian, S.L., Sherry, R., Restifo, N.P., Hubicki, A.M., Robinson, M.R., Raffeld, M., Duray, P., Seipp, C.A., Rogers-Freezer, L., Morton, K.E., Mavroukakis, S.A., White, D.E., and Rosenberg, S.A. (2002). Cancer regression and autoimmunity in patients after clonal repopulation with antitumor lymphocytes. Science, 298, 5594, 850-854.

Elboim, M., Gazit, R., Gur, C., Ghadially, H., Betser-Cohen, G., and Mandelboim, O. (2010). Tumor immunoediting by NKp46. J Immunol, 184, 10, 5637-5644.

Fang, L., Lonsdorf, A.S., and Hwang, S.T. (2008). Immunotherapy for advanced melanoma. J Invest Dermatol, 128, 11, 2596-2605.

Farag, S.S., and Caligiuri, M.A. (2006). Human natural killer cell development and biology. Blood Rev, 20, 3, 123-137.

Farzad, Z., Cochran, A.J., McBride, W.H., Gray, J.D., Wong, V., and Morton, D.L. (1990). Lymphocyte subset alterations in nodes regional to human melanoma. Cancer Res, 50, 12, 3585-3588.

Fehniger, T.A., and Caligiuri, M.A. (2001). Interleukin 15: biology and relevance to human disease. Blood, 97, 1, 14-32.

Fernandez, N.C., Lozier, A., Flament, C., Ricciardi-Castagnoli, P., Bellet, D., Suter, M., Perricaudet, M., Tursz, T., Maraskovsky, E., and Zitvogel, L. (1999). Dendritic cells directly trigger NK cell functions: cross-talk relevant in innate anti-tumor immune responses in vivo. Nat Med, 5, 4, 405-411.

Ferrone, S., and Marincola, F.M. (1995). Loss of HLA class I antigens by melanoma cells: molecular mechanisms, functional significance and clinical relevance. Immunol Today, 16, 10, 487-494.

Fewkes, N.M., and Mackall, C.L. (2010). Novel gamma-chain cytokines as candidate immune modulators in immune therapies for cancer. Cancer J, 16, 4, 392-398.

Flaherty, L.E., and Gadgeel, S.M. (2002). Biochemotherapy of melanoma. Semin Oncol, 29, 5, 446-455.

Fogler, W.E., Volker, K., McCormick, K.L., Watanabe, M., Ortaldo, J.R., and Wiltrout, R.H. (1996). NK cell infiltration into lung, liver, and subcutaneous B16 melanoma is mediated by VCAM-1/VLA-4 interaction. J Immunol, 156, 12, 4707-4714.

Fregni, G., Perier, A., Pittari, G., Jacobelli, S., Sastre, X., Gervois, N.I., Allard, M., Bercovici, N., Avril, M.F., and Caignard, A. (2011). Unique functional status of Natural Killer cells in metastatic stage IV melanoma patients and its modulation by chemotherapy. Clin Cancer Res,

Galea-Lauri, J., Darling, D., Gan, S.U., Krivochtchapov, L., Kuiper, M., Gaken, J., Souberbielle, B., and Farzaneh, F. (1999). Expression of a variant of CD28 on a subpopulation of human NK cells: implications for B7-mediated stimulation of NK cells. J Immunol, 163, 1, 62-70.

Gately, M.K., Wolitzky, A.G., Quinn, P.M., and Chizzonite, R. (1992). Regulation of human cytolytic lymphocyte responses by interleukin-12. Cell Immunol, 143, 1, 127-142.

Geller, M.A., Cooley, S., Judson, P.L., Ghebre, R., Carson, L.F., Argenta, P.A., Jonson, A.L., Panoskaltsis-Mortari, A., Curtsinger, J., McKenna, D., Dusenbery, K., Bliss, R., Downs, L.S., and Miller, J.S. (2011). A phase II study of allogeneic natural killer cell 
therapy to treat patients with recurrent ovarian and breast cancer. Cytotherapy, 13, 1, 98-107.

Ghiringhelli, F., Menard, C., Terme, M., Flament, C., Taieb, J., Chaput, N., Puig, P.E., Novault, S., Escudier, B., Vivier, E., Lecesne, A., Robert, C., Blay, J.Y., Bernard, J., Caillat-Zucman, S., Freitas, A., Tursz, T., Wagner-Ballon, O., Capron, C., Vainchencker, W., Martin, F., and Zitvogel, L. (2005). CD4+CD25+ regulatory T cells inhibit natural killer cell functions in a transforming growth factor-betadependent manner. J Exp Med, 202, 8, 1075-1085.

Giebel, S., Locatelli, F., Lamparelli, T., Velardi, A., Davies, S., Frumento, G., Maccario, R., Bonetti, F., Wojnar, J., Martinetti, M., Frassoni, F., Giorgiani, G., Bacigalupo, A., and Holowiecki, J. (2003). Survival advantage with KIR ligand incompatibility in hematopoietic stem cell transplantation from unrelated donors. Blood, 102, 3, 814819.

Gilfillan, S., Chan, C.J., Cella, M., Haynes, N.M., Rapaport, A.S., Boles, K.S., Andrews, D.M., Smyth, M.J., and Colonna, M. (2008). DNAM-1 promotes activation of cytotoxic lymphocytes by nonprofessional antigen-presenting cells and tumors. J Exp Med, 205, 13, 2965-2973.

Greenlee, R.T., Hill-Harmon, M.B., Murray, T., and Thun, M. (2001). Cancer statistics, 2001. CA Cancer J Clin, 51, 1, 15-36.

Groh, V., Wu, J., Yee, C., and Spies, T. (2002). Tumour-derived soluble MIC ligands impair expression of NKG2D and T-cell activation. Nature, 419, 6908, 734-738.

Guerra, N., Tan, Y.X., Joncker, N.T., Choy, A., Gallardo, F., Xiong, N., Knoblaugh, S., Cado, D., Greenberg, N.M., and Raulet, D.H. (2008). NKG2D-deficient mice are defective in tumor surveillance in models of spontaneous malignancy. Immunity, 28, 4, 571580 .

Haass, N.K., Smalley, K.S., Li, L., and Herlyn, M. (2005). Adhesion, migration and communication in melanocytes and melanoma. Pigment Cell Res, 18, 3, 150-159.

Hanna, N. (1982). Inhibition of experimental tumor metastasis by selective activation of natural killer cells. Cancer Res, 42, 4, 1337-1342.

Hayakawa, Y., and Smyth, M.J. (2006). NKG2D and cytotoxic effector function in tumor immune surveillance. Semin Immunol, 18, 3, 176-185.

Heinzerling, L., Dummer, R., Pavlovic, J., Schultz, J., Burg, G., and Moelling, K. (2002). Tumor regression of human and murine melanoma after intratumoral injection of IL-12-encoding plasmid DNA in mice. Exp Dermatol, 11, 3, 232-240.

Herberman, R.B., Nunn, M.E., Holden, H.T., and Lavrin, D.H. (1975). Natural cytotoxic reactivity of mouse lymphoid cells against syngeneic and allogeneic tumors. II. Characterization of effector cells. Int J Cancer, 16, 2, 230-239.

Hersey, P., Edwards, A., and McCarthy, W.H. (1980). Tumour-related changes in natural killer cell activity in melanoma patients. Influence of stage of disease, tumour thickness and age of patients. Int J Cancer, 25, 2, 187-194.

Hersey, P., Hobbs, A., Edwards, A., McCarthy, W.H., and McGovern, V.J. (1982). Relationship between natural killer cell activity and histological features of lymphocyte infiltration and partial regression of the primary tumor in melanoma patients. Cancer Res, 42, 1, 363-368.

Hersey, P., and Zhang, X.D. (2001). How melanoma cells evade trail-induced apoptosis. Nat Rev Cancer, 1, 2, 142-150. 
Hill, L.L., Perussia, B., McCue, P.A., and Korngold, R. (1994). Effect of human natural killer cells on the metastatic growth of human melanoma xenografts in mice with severe combined immunodeficiency. Cancer Res, 54, 3, 763-770.

Hirschowitz, E.A., and Crystal, R.G. (1999). Adenovirus-mediated expression of interleukin12 induces natural killer cell activity and complements adenovirus-directed gp75 treatment of melanoma lung metastases. Am J Respir Cell Mol Biol, 20, 5, 935-941.

Huang, Y., Wang, Y., Li, Y., Guo, K., and He, Y. (2011). Role of sorafenib and sunitinib in the induction of expressions of NKG2D ligands in nasopharyngeal carcinoma with high expression of ABCG(2). J Cancer Res Clin Oncol, 137, 5, 829-837.

Igarashi, T., Wynberg, J., Srinivasan, R., Becknell, B., McCoy, J.P., Jr., Takahashi, Y., Suffredini, D.A., Linehan, W.M., Caligiuri, M.A., and Childs, R.W. (2004). Enhanced cytotoxicity of allogeneic NK cells with killer immunoglobulin-like receptor ligand incompatibility against melanoma and renal cell carcinoma cells. Blood, 104, 1, 170 177.

Iguchi-Manaka, A., Kai, H., Yamashita, Y., Shibata, K., Tahara-Hanaoka, S., Honda, S., Yasui, T., Kikutani, H., Shibuya, K., and Shibuya, A. (2008). Accelerated tumor growth in mice deficient in DNAM-1 receptor. J Exp Med, 205, 13, 2959-2964.

Iyengar, R., Handgretinger, R., Babarin-Dorner, A., Leimig, T., Otto, M., Geiger, T.L., Holladay, M.S., Houston, J., and Leung, W. (2003). Purification of human natural killer cells using a clinical-scale immunomagnetic method. Cytotherapy, 5, 6, 479484 .

Jager, M.J., Hurks, H.M., Levitskaya, J., and Kiessling, R. (2002). HLA expression in uveal melanoma: there is no rule without some exception. Hum Immunol, 63, 6, 444-451.

Jaime-Ramirez, A.C., Mundy-Bosse, B.L., Kondadasula, S., Jones, N.B., Roda, J.M., Mani, A., Parihar, R., Karpa, V., Papenfuss, T.L., LaPerle, K.M., Biller, E., Lehman, A., Chaudhury, A.R., Jarjoura, D., Burry, R.W., and Carson, W.E., 3rd. (2011). IL-12 enhances the antitumor actions of trastuzumab via NK cell IFN-gamma production. J Immunol, 186, 6, 3401-3409.

Jin, G.H., Hirano, T., and Murakami, M. (2008). Combination treatment with IL-2 and antiIL-2 mAbs reduces tumor metastasis via NK cell activation. Int Immunol, 20, 6, 783789.

Jovic, V., Konjevic, G., Radulovic, S., Jelic, S., and Spuzic, I. (2001). Impaired perforindependent NK cell cytotoxicity and proliferative activity of peripheral blood T cells is associated with metastatic melanoma. Tumori, 87, 5, 324-329.

Karre, K. (1991). MHC gene control of the natural killer system at the level of the target and the host. Semin Cancer Biol, 2, 5, 295-309.

Kiessling, R., Klein, E., Pross, H., and Wigzell, H. (1975a). "Natural" killer cells in the mouse. II. Cytotoxic cells with specificity for mouse Moloney leukemia cells. Characteristics of the killer cell. Eur J Immunol, 5, 2, 117-121.

Kiessling, R., Klein, E., and Wigzell, H. (1975b). "Natural" killer cells in the mouse. I. Cytotoxic cells with specificity for mouse Moloney leukemia cells. Specificity and distribution according to genotype. Eur J Immunol, 5, 2, 112-117.

Kim, H., Kim, S.H., Kim, M.J., Kim, S.J., Park, S.J., Chung, J.S., Bae, J.H., and Kang, C.D. (2011). EGFR Inhibitors Enhanced the Susceptibility to NK Cell-mediated Lysis of Lung Cancer Cells. J Immunother, 34, 4, 372-381. 
Kohga, K., Takehara, T., Tatsumi, T., Ishida, H., Miyagi, T., Hosui, A., and Hayashi, N. (2010). Sorafenib inhibits the shedding of major histocompatibility complex class Irelated chain A on hepatocellular carcinoma cells by down-regulating a disintegrin and metalloproteinase 9. Hepatology, 51, 4, 1264-1273.

Kohno, K., Kataoka, J., Ohtsuki, T., Suemoto, Y., Okamoto, I., Usui, M., Ikeda, M., and Kurimoto, M. (1997). IFN-gamma-inducing factor (IGIF) is a costimulatory factor on the activation of Th1 but not Th2 cells and exerts its effect independently of IL12. J Immunol, 158, 4, 1541-1550.

Konjevic, G., Mirjacic Martinovic, K., Vuletic, A., and Babovic, N. (2010). In-vitro IL-2 or IFN-alpha-induced NKG2D and CD161 NK cell receptor expression indicates novel aspects of NK cell activation in metastatic melanoma patients. Melanoma Res, 20, 6, 459-467.

Konjevic, G., Mirjacic Martinovic, K., Vuletic, A., Jovic, V., Jurisic, V., Babovic, N., and Spuzic, I. (2007). Low expression of CD161 and NKG2D activating NK receptor is associated with impaired NK cell cytotoxicity in metastatic melanoma patients. Clin Exp Metastasis, 24, 1, 1-11.

Kornstein, M.J., Stewart, R., and Elder, D.E. (1987). Natural killer cells in the host response to melanoma. Cancer Res, 47, 5, 1411-1412.

Kroger, A., Koster, M., Schroeder, K., Hauser, H., and Mueller, P.P. (2002). Activities of IRF1. J Interferon Cytokine Res, 22, 1, 5-14.

Lakshmikanth, T., Burke, S., Ali, T.H., Kimpfler, S., Ursini, F., Ruggeri, L., Capanni, M., Umansky, V., Paschen, A., Sucker, A., Pende, D., Groh, V., Biassoni, R., Hoglund, P., Kato, M., Shibuya, K., Schadendorf, D., Anichini, A., Ferrone, S., Velardi, A., Karre, K., Shibuya, A., Carbone, E., and Colucci, F. (2009). NCRs and DNAM-1 mediate NK cell recognition and lysis of human and mouse melanoma cell lines in vitro and in vivo. J Clin Invest, 119, 5, 1251-1263.

Lamont, A.G., and Adorini, L. (1996). IL-12: a key cytokine in immune regulation. Immunol Today, 17, 5, 214-217.

Lanier, L.L. (2005). NK cell recognition. Annu Rev Immunol, 23, 225-274.

Law, T.M., Motzer, R.J., Mazumdar, M., Sell, K.W., Walther, P.J., O'Connell, M., Khan, A., Vlamis, V., Vogelzang, N.J., and Bajorin, D.F. (1995). Phase III randomized trial of interleukin-2 with or without lymphokine-activated killer cells in the treatment of patients with advanced renal cell carcinoma. Cancer, 76, 5, 824-832.

Le Garff-Tavernier, M., Beziat, V., Decocq, J., Siguret, V., Gandjbakhch, F., Pautas, E., Debre, P., Merle-Beral, H., and Vieillard, V. (2010). Human NK cells display major phenotypic and functional changes over the life span. Aging Cell, 9, 4, 527-535.

Lieberman, J. (2003). The ABCs of granule-mediated cytotoxicity: new weapons in the arsenal. Nat Rev Immunol, 3, 5, 361-370.

Liu, H., Lightfoot, R., and Stevens, J.L. (1996). Activation of heat shock factor by alkylating agents is triggered by glutathione depletion and oxidation of protein thiols. J Biol Chem, 271, 9, 4805-4812.

Ljunggren, H.G., and Karre, K. (1990). In search of the 'missing self': MHC molecules and NK cell recognition. Immunol Today, 11, 7, 237-244.

Ljunggren, H.G., and Malmberg, K.J. (2007). Prospects for the use of NK cells in immunotherapy of human cancer. Nat Rev Immunol, 7, 5, 329-339. 
Long, E.O. (1999). Regulation of immune responses through inhibitory receptors. Annu Rev Immunol, 17, 875-904.

Long, E.O., Barber, D.F., Burshtyn, D.N., Faure, M., Peterson, M., Rajagopalan, S., Renard, V., Sandusky, M., Stebbins, C.C., Wagtmann, N., and Watzl, C. (2001). Inhibition of natural killer cell activation signals by killer cell immunoglobulin-like receptors (CD158). Immunol Rev, 181, 223-233.

Lotze, M.T., Rubin, J.T., and Zeh, H.J. (1992). New biologic agents come to bat for cancer therapy. Curr Opin Oncol, 4, 6, 1116-1123.

Loza, M.J., Zamai, L., Azzoni, L., Rosati, E., and Perussia, B. (2002). Expression of type 1 (interferon gamma) and type 2 (interleukin-13, interleukin-5) cytokines at distinct stages of natural killer cell differentiation from progenitor cells. Blood, 99, 4, 12731281.

Luci, C., Reynders, A., Ivanov, II, Cognet, C., Chiche, L., Chasson, L., Hardwigsen, J., Anguiano, E., Banchereau, J., Chaussabel, D., Dalod, M., Littman, D.R., Vivier, E., and Tomasello, E. (2009). Influence of the transcription factor RORgammat on the development of NKp46+ cell populations in gut and skin. Nat Immunol, 10, 1, 75-82.

Lundqvist, A., Abrams, S.I., Schrump, D.S., Alvarez, G., Suffredini, D., Berg, M., and Childs, R. (2006). Bortezomib and depsipeptide sensitize tumors to tumor necrosis factorrelated apoptosis-inducing ligand: a novel method to potentiate natural killer cell tumor cytotoxicity. Cancer Res, 66, 14, 7317-7325.

Lundqvist, A., McCoy, J.P., Samsel, L., and Childs, R. (2007). Reduction of GVHD and enhanced antitumor effects after adoptive infusion of alloreactive Ly49-mismatched NK cells from MHC-matched donors. Blood, 109, 8, 3603-3606.

Lundqvist, A., Yokoyama, H., Smith, A., Berg, M., and Childs, R. (2009). Bortezomib treatment and regulatory $\mathrm{T}$-cell depletion enhance the antitumor effects of adoptively infused NK cells. Blood, 113, 24, 6120-6127.

Ma, D., and Niederkorn, J.Y. (1995). Transforming growth factor-beta down-regulates major histocompatibility complex class I antigen expression and increases the susceptibility of uveal melanoma cells to natural killer cell-mediated cytolysis. Immunology, 86, 2, 263-269.

Mackensen, A., Carcelain, G., Viel, S., Raynal, M.C., Michalaki, H., Triebel, F., Bosq, J., and Hercend, T. (1994). Direct evidence to support the immunosurveillance concept in a human regressive melanoma. J Clin Invest, 93, 4, 1397-1402.

Marincola, F.M., Jaffee, E.M., Hicklin, D.J., and Ferrone, S. (2000). Escape of human solid tumors from T-cell recognition: molecular mechanisms and functional significance. Adv Immunol, 74, 181-273.

Markel, G., Lieberman, N., Katz, G., Arnon, T.I., Lotem, M., Drize, O., Blumberg, R.S., BarHaim, E., Mader, R., Eisenbach, L., and Mandelboim, O. (2002). CD66a interactions between human melanoma and NK cells: a novel class I MHC-independent inhibitory mechanism of cytotoxicity. J Immunol, 168, 6, 2803-2810.

Markel, G., Seidman, R., Besser, M.J., Zabari, N., Ortenberg, R., Shapira, R., Treves, A.J., Loewenthal, R., Orenstein, A., Nagler, A., and Schachter, J. (2009). Natural killer lysis receptor (NKLR)/NKLR-ligand matching as a novel approach for enhancing anti-tumor activity of allogeneic NK cells. PLoS One, 4, 5, e5597. 
Markovic, S.N., and Murasko, D.M. (1991). Role of natural killer and T-cells in interferon induced inhibition of spontaneous metastases of the B16F10L murine melanoma. Cancer Res, 51, 4, 1124-1128.

Markovic, S.N., and Murasko, D.M. (1990). Neoadjuvant immunotherapy with interferon of the spontaneously metastasizing murine B16F10L melanoma. Int J Cancer, 45, 4, 788-794.

Martin-Fontecha, A., Thomsen, L.L., Brett, S., Gerard, C., Lipp, M., Lanzavecchia, A., and Sallusto, F. (2004). Induced recruitment of NK cells to lymph nodes provides IFNgamma for T(H)1 priming. Nat Immunol, 5, 12, 1260-1265.

Meier, F., Satyamoorthy, K., Nesbit, M., Hsu, M.Y., Schittek, B., Garbe, C., and Herlyn, M. (1998). Molecular events in melanoma development and progression. Front Biosci, 3, D1005-1010.

Meyer-Monard, S., Passweg, J., Siegler, U., Kalberer, C., Koehl, U., Rovo, A., Halter, J., Stern, M., Heim, D., Alois Gratwohl, J.R., and Tichelli, A. (2009). Clinical-grade purification of natural killer cells in haploidentical hematopoietic stem cell transplantation. Transfusion, 49, 2, 362-371.

Miller, J.S., Soignier, Y., Panoskaltsis-Mortari, A., McNearney, S.A., Yun, G.H., Fautsch, S.K., McKenna, D., Le, C., Defor, T.E., Burns, L.J., Orchard, P.J., Blazar, B.R., Wagner, J.E., Slungaard, A., Weisdorf, D.J., Okazaki, I.J., and McGlave, P.B. (2005). Successful adoptive transfer and in vivo expansion of human haploidentical NK cells in patients with cancer. Blood, 105, 8, 3051-3057.

Miller, J.S., Tessmer-Tuck, J., Pierson, B.A., Weisdorf, D., McGlave, P., Blazar, B.R., Katsanis, E., Verfaillie, C., Lebkowski, J., Radford, J., Jr., and Burns, L.J. (1997). Low dose subcutaneous interleukin-2 after autologous transplantation generates sustained in vivo natural killer cell activity. Biol Blood Marrow Transplant, 3, 1, 34-44.

Moretta, A., Bottino, C., Vitale, M., Pende, D., Cantoni, C., Mingari, M.C., Biassoni, R., and Moretta, L. (2001). Activating receptors and coreceptors involved in human natural killer cell-mediated cytolysis. Annu Rev Immunol, 19, 197-223.

Morris, M.A., and Ley, K. (2004). Trafficking of natural killer cells. Curr Mol Med, 4, 4, 431438.

Muller, C., Pehamberger, H., Binder, M., and Zielinski, C.C. (1989). Defective interferonaugmented natural killer cell activity in patients with metastatic malignant melanoma. J Cancer Res Clin Oncol, 115, 4, 393-396.

Munger, W., DeJoy, S.Q., Jeyaseelan, R., Sr., Torley, L.W., Grabstein, K.H., Eisenmann, J., Paxton, R., Cox, T., Wick, M.M., and Kerwar, S.S. (1995). Studies evaluating the antitumor activity and toxicity of interleukin-15, a new $\mathrm{T}$ cell growth factor: comparison with interleukin-2. Cell Immunol, 165, 2, 289-293.

Naume, B., Gately, M., and Espevik, T. (1992). A comparative study of IL-12 (cytotoxic lymphocyte maturation factor)-, IL-2-, and IL-7-induced effects on immunomagnetically purified CD56+ NK cells. J Immunol, 148, 8, 2429-2436.

Nguyen, T., Thomas, W., Zhang, X.D., Gray, C., and Hersey, P. (2000). Immunologicallymediated tumour cell apoptosis: the role of TRAIL in T cell and cytokine-mediated responses to melanoma. Forum (Genova), 10, 3, 243-252.

Okamura, H., Tsutsi, H., Komatsu, T., Yutsudo, M., Hakura, A., Tanimoto, T., Torigoe, K., Okura, T., Nukada, Y., Hattori, K., and et al. (1995). Cloning of a new cytokine that induces IFN-gamma production by T cells. Nature, 378, 6552, 88-91. 
Oppenheim, D.E., Roberts, S.J., Clarke, S.L., Filler, R., Lewis, J.M., Tigelaar, R.E., Girardi, M., and Hayday, A.C. (2005). Sustained localized expression of ligand for the activating NKG2D receptor impairs natural cytotoxicity in vivo and reduces tumor immunosurveillance. Nat Immunol, 6, 9, 928-937.

Osaki, T., Peron, J.M., Cai, Q., Okamura, H., Robbins, P.D., Kurimoto, M., Lotze, M.T., and Tahara, H. (1998). IFN-gamma-inducing factor/IL-18 administration mediates IFNgamma- and IL-12-independent antitumor effects. J Immunol, 160, 4, 1742-1749.

Pandolfi, F., Boyle, L.A., Trentin, L., Kurnick, J.T., Isselbacher, K.J., and Gattoni-Celli, S. (1991). Expression of HLA-A2 antigen in human melanoma cell lines and its role in T-cell recognition. Cancer Res, 51, 12, 3164-3170.

Parrish-Novak, J., Dillon, S.R., Nelson, A., Hammond, A., Sprecher, C., Gross, J.A., Johnston, J., Madden, K., Xu, W., West, J., Schrader, S., Burkhead, S., Heipel, M., Brandt, C., Kuijper, J.L., Kramer, J., Conklin, D., Presnell, S.R., Berry, J., Shiota, F., Bort, S., Hambly, K., Mudri, S., Clegg, C., Moore, M., Grant, F.J., Lofton-Day, C., Gilbert, T., Rayond, F., Ching, A., Yao, L., Smith, D., Webster, P., Whitmore, T., Maurer, M., Kaushansky, K., Holly, R.D., and Foster, D. (2000). Interleukin 21 and its receptor are involved in NK cell expansion and regulation of lymphocyte function. Nature, 408, 6808, 57-63.

Paul, P., Rouas-Freiss, N., Khalil-Daher, I., Moreau, P., Riteau, B., Le Gal, F.A., Avril, M.F., Dausset, J., Guillet, J.G., and Carosella, E.D. (1998). HLA-G expression in melanoma: a way for tumor cells to escape from immunosurveillance. Proc Natl Acad Sci U S A, 95, 8, 4510-4515.

Pende, D., Accame, L., Pareti, L., Mazzocchi, A., Moretta, A., Parmiani, G., and Moretta, L. (1998). The susceptibility to natural killer cell-mediated lysis of HLA class I-positive melanomas reflects the expression of insufficient amounts of different HLA class I alleles. Eur J Immunol, 28, 8, 2384-2394.

Pende, D., Cantoni, C., Rivera, P., Vitale, M., Castriconi, R., Marcenaro, S., Nanni, M., Biassoni, R., Bottino, C., Moretta, A., and Moretta, L. (2001). Role of NKG2D in tumor cell lysis mediated by human NK cells: cooperation with natural cytotoxicity receptors and capability of recognizing tumors of nonepithelial origin. Eur J Immunol, 31, 4, 1076-1086.

Pende, D., Parolini, S., Pessino, A., Sivori, S., Augugliaro, R., Morelli, L., Marcenaro, E., Accame, L., Malaspina, A., Biassoni, R., Bottino, C., Moretta, L., and Moretta, A. (1999). Identification and molecular characterization of NKp30, a novel triggering receptor involved in natural cytotoxicity mediated by human natural killer cells. $J$ Exp Med, 190, 10, 1505-1516.

Pende, D., Rivera, P., Marcenaro, S., Chang, C.C., Biassoni, R., Conte, R., Kubin, M., Cosman, D., Ferrone, S., Moretta, L., and Moretta, A. (2002). Major histocompatibility complex class I-related chain A and UL16-binding protein expression on tumor cell lines of different histotypes: analysis of tumor susceptibility to NKG2D-dependent natural killer cell cytotoxicity. Cancer Res, 62, 21, 6178-6186.

Perussia, B., Chan, S.H., D'Andrea, A., Tsuji, K., Santoli, D., Pospisil, M., Young, D., Wolf, S.F., and Trinchieri, G. (1992). Natural killer (NK) cell stimulatory factor or IL-12 has differential effects on the proliferation of TCR-alpha beta+, TCR-gamma delta+ T lymphocytes, and NK cells. J Immunol, 149, 11, 3495-3502. 
Pogge von Strandmann, E., Simhadri, V.R., von Tresckow, B., Sasse, S., Reiners, K.S., Hansen, H.P., Rothe, A., Boll, B., Simhadri, V.L., Borchmann, P., McKinnon, P.J., Hallek, M., and Engert, A. (2007). Human leukocyte antigen-B-associated transcript 3 is released from tumor cells and engages the NKp30 receptor on natural killer cells. Immunity, 27, 6, 965-974.

Porgador, A., Mandelboim, O., Restifo, N.P., and Strominger, J.L. (1997). Natural killer cell lines kill autologous beta2-microglobulin-deficient melanoma cells: implications for cancer immunotherapy. Proc Natl Acad Sci U S A, 94, 24, 13140-13145.

Porgador, A., Tzehoval, E., Vadai, E., Feldman, M., and Eisenbach, L. (1995). Combined vaccination with major histocompatibility class I and interleukin 2 gene-transduced melanoma cells synergizes the cure of postsurgical established lung metastases. Cancer Res, 55, 21, 4941-4949.

Quan, W., Jr., Ramirez, M., Taylor, C., Quan, F., Vinogradov, M., and Walker, P. (2005). Administration of high-dose continuous infusion interleukin-2 to patients age 70 or over. Cancer Biother Radiopharm, 20, 1, 11-15.

Quereux, G., Pandolfino, M.C., Knol, A.C., Khammari, A., Volteau, C., Nguyen, J.M., and Dreno, B. (2007). Tissue prognostic markers for adoptive immunotherapy in melanoma. Eur J Dermatol, 17, 4, 295-301.

Romagne, F., Andre, P., Spee, P., Zahn, S., Anfossi, N., Gauthier, L., Capanni, M., Ruggeri, L., Benson, D.M., Jr., Blaser, B.W., Della Chiesa, M., Moretta, A., Vivier, E., Caligiuri, M.A., Velardi, A., and Wagtmann, N. (2009). Preclinical characterization of 1-7F9, a novel human anti-KIR receptor therapeutic antibody that augments natural killer-mediated killing of tumor cells. Blood, 114, 13, 2667-2677.

Rosenberg, S.A. (1997). Cancer vaccines based on the identification of genes encoding cancer regression antigens. Immunol Today, 18, 4, 175-182.

Rosenberg, S.A., Lotze, M.T., Muul, L.M., Chang, A.E., Avis, F.P., Leitman, S., Linehan, W.M., Robertson, C.N., Lee, R.E., Rubin, J.T., and et al. (1987). A progress report on the treatment of 157 patients with advanced cancer using lymphokine-activated killer cells and interleukin-2 or high-dose interleukin-2 alone. N Engl J Med, 316, 15, 889-897.

Rosenberg, S.A., Lotze, M.T., Muul, L.M., Leitman, S., Chang, A.E., Ettinghausen, S.E., Matory, Y.L., Skibber, J.M., Shiloni, E., Vetto, J.T., and et al. (1985). Observations on the systemic administration of autologous lymphokine-activated killer cells and recombinant interleukin-2 to patients with metastatic cancer. N Engl J Med, 313, 23, 1485-1492.

Ross, J.S., and Fletcher, J.A. (1998). The HER-2/neu Oncogene in Breast Cancer: Prognostic Factor, Predictive Factor, and Target for Therapy. Oncologist, 3, 4, 237-252.

Routes, J.M. (1992). IFN increases class I MHC antigen expression on adenovirus-infected human cells without inducing resistance to natural killer cell killing. J Immunol, 149, 7, 2372-2377.

Ruggeri, L., Capanni, M., Urbani, E., Perruccio, K., Shlomchik, W.D., Tosti, A., Posati, S., Rogaia, D., Frassoni, F., Aversa, F., Martelli, M.F., and Velardi, A. (2002). Effectiveness of donor natural killer cell alloreactivity in mismatched hematopoietic transplants. Science, 295, 5562, 2097-2100.

Ruggeri, L., Mancusi, A., Capanni, M., Urbani, E., Carotti, A., Aloisi, T., Stern, M., Pende, D., Perruccio, K., Burchielli, E., Topini, F., Bianchi, E., Aversa, F., Martelli, M.F., and 
Velardi, A. (2007). Donor natural killer cell allorecognition of missing self in haploidentical hematopoietic transplantation for acute myeloid leukemia: challenging its predictive value. Blood, 110, 1, 433-440.

Santoni, A., Piccoli, M., Ortaldo, J.R., Mason, L., Wiltrout, R.H., and Herberman, R.B. (1985). Changes in number and density of large granular lymphocytes upon in vivo augmentation of mouse natural killer activity. J Immunol, 134, 4, 2799-2810.

Schwartz, R.H. (1990). A cell culture model for T lymphocyte clonal anergy. Science, 248, 4961, 1349-1356.

Seidel, M.G., Freissmuth, M., Pehamberger, H., and Micksche, M. (1998). Stimulation of natural killer activity in peripheral blood lymphocytes of healthy donors and melanoma patients in vitro: synergism between interleukin (IL)-12 and IL-15 or IL12 and IL-2. Naunyn Schmiedebergs Arch Pharmacol, 358, 3, 382-389.

Shankaran, V., Ikeda, H., Bruce, A.T., White, J.M., Swanson, P.E., Old, L.J., and Schreiber, R.D. (2001). IFNgamma and lymphocytes prevent primary tumour development and shape tumour immunogenicity. Nature, 410, 6832, 1107-1111.

Shibuya, A., Campbell, D., Hannum, C., Yssel, H., Franz-Bacon, K., McClanahan, T., Kitamura, T., Nicholl, J., Sutherland, G.R., Lanier, L.L., and Phillips, J.H. (1996). DNAM-1, a novel adhesion molecule involved in the cytolytic function of $\mathrm{T}$ lymphocytes. Immunity, 4, 6, 573-581.

Sibbitt, W.L., Jr., Bankhurst, A.D., Jumonville, A.J., Saiki, J.H., Saiers, J.H., and Doberneck, R.C. (1984). Defects in natural killer cell activity and interferon response in human lung carcinoma and malignant melanoma. Cancer Res, 44, 2, 852-856.

Smyth, M.J., Hayakawa, Y., Takeda, K., and Yagita, H. (2002). New aspects of natural-killercell surveillance and therapy of cancer. Nat Rev Cancer, 2, 11, 850-861.

Smyth, M.J., Swann, J., Cretney, E., Zerafa, N., Yokoyama, W.M., and Hayakawa, Y. (2005). NKG2D function protects the host from tumor initiation. J Exp Med, 202, 5, 583-588.

Solana, R., Casado, J.G., Delgado, E., DelaRosa, O., Marin, J., Duran, E., Pawelec, G., and Tarazona, R. (2007). Lymphocyte activation in response to melanoma: interaction of NK-associated receptors and their ligands. Cancer Immunol Immunother, 56, 1, 101109.

Soriani, A., Zingoni, A., Cerboni, C., Iannitto, M.L., Ricciardi, M.R., Di Gialleonardo, V., Cippitelli, M., Fionda, C., Petrucci, M.T., Guarini, A., Foa, R., and Santoni, A. (2009). ATM-ATR-dependent up-regulation of DNAM-1 and NKG2D ligands on multiple myeloma cells by therapeutic agents results in enhanced NK-cell susceptibility and is associated with a senescent phenotype. Blood, 113, 15, 3503-3511.

Spanholtz, J., Tordoir, M., Eissens, D., Preijers, F., van der Meer, A., Joosten, I., Schaap, N., de Witte, T.M., and Dolstra, H. (2010). High log-scale expansion of functional human natural killer cells from umbilical cord blood CD34-positive cells for adoptive cancer immunotherapy. PLoS One, 5, 2, e9221.

Srivastava, S., Salim, N., and Robertson, M.J. (2010). Interleukin-18: biology and role in the immunotherapy of cancer. Curr Med Chem, 17, 29, 3353-3357.

Street, S.E., Cretney, E., and Smyth, M.J. (2001). Perforin and interferon-gamma activities independently control tumor initiation, growth, and metastasis. Blood, 97, 1, 192197.

Strid, J., Roberts, S.J., Filler, R.B., Lewis, J.M., Kwong, B.Y., Schpero, W., Kaplan, D.H., Hayday, A.C., and Girardi, M. (2008). Acute upregulation of an NKG2D ligand 
promotes rapid reorganization of a local immune compartment with pleiotropic effects on carcinogenesis. Nat Immunol, 9, 2, 146-154.

Talmadge, J.E., Phillips, H., Schindler, J., Tribble, H., and Pennington, R. (1987). Systematic preclinical study on the therapeutic properties of recombinant human interleukin 2 for the treatment of metastatic disease. Cancer Res, 47, 21, 5725-5732.

Taniguchi, K., Karre, K., and Klein, G. (1985). Lung colonization and metastasis by disseminated B16 melanoma cells: H-2 associated control at the level of the host and the tumor cell. Int J Cancer, 36, 4, 503-510.

Terme, M., Ullrich, E., Delahaye, N.F., Chaput, N., and Zitvogel, L. (2008). Natural killer cell-directed therapies: moving from unexpected results to successful strategies. Nat Immunol, 9, 5, 486-494.

Thies, A., Moll, I., Berger, J., Wagener, C., Brummer, J., Schulze, H.J., Brunner, G., and Schumacher, U. (2002). CEACAM1 expression in cutaneous malignant melanoma predicts the development of metastatic disease. J Clin Oncol, 20, 10, 2530-2536.

Trapani, J.A., Davis, J., Sutton, V.R., and Smyth, M.J. (2000). Proapoptotic functions of cytotoxic lymphocyte granule constituents in vitro and in vivo. Curr Opin Immunol, $12,3,323-329$.

Trinchieri, G. (1998). Interleukin-12: a cytokine at the interface of inflammation and immunity. Adv Immunol, 70, 83-243.

Trinchieri, G., and Perussia, B. (1984). Human natural killer cells: biologic and pathologic aspects. Lab Invest, 50, 5, 489-513.

Tsao, H., Atkins, M.B., and Sober, A.J. (2004). Management of cutaneous melanoma. N Engl J Med, 351, 10, 998-1012.

Vahlne, G., Lindholm, K., Meier, A., Wickstrom, S., Lakshmikanth, T., Brennan, F., Wilken, M., Nielsen, R., Romagne, F., Wagtmann, N.R., Karre, K., and Johansson, M.H. (2010). In vivo tumor cell rejection induced by NK cell inhibitory receptor blockade: maintained tolerance to normal cells even in the presence of IL-2. Eur J Immunol, 40, 3, 813-823.

Velardi, A., Ruggeri, L., Mancusi, A., Aversa, F., and Christiansen, F.T. (2009). Natural killer cell allorecognition of missing self in allogeneic hematopoietic transplantation: a tool for immunotherapy of leukemia. Curr Opin Immunol, 21, 5, 525-530.

Vetter, C.S., Groh, V., thor Straten, P., Spies, T., Brocker, E.B., and Becker, J.C. (2002). Expression of stress-induced MHC class I related chain molecules on human melanoma. J Invest Dermatol, 118, 4, 600-605.

Vetter, C.S., Lieb, W., Brocker, E.B., and Becker, J.C. (2004). Loss of nonclassical MHC molecules MIC-A/B expression during progression of uveal melanoma. Br J Cancer, 91, 8, 1495-1499.

Wang, G., Tschoi, M., Spolski, R., Lou, Y., Ozaki, K., Feng, C., Kim, G., Leonard, W.J., and Hwu, P. (2003). In vivo antitumor activity of interleukin 21 mediated by natural killer cells. Cancer Res, 63, 24, 9016-9022.

Wang, R.F., and Rosenberg, S.A. (1996). Human tumor antigens recognized by T lymphocytes: implications for cancer therapy. J Leukoc Biol, 60, 3, 296-309.

Wen, D.R., Hoon, D.S., Chang, C., and Cochran, A.J. (1989). Variations in lymphokine generation by individual lymph nodes draining human malignant tumors. Cancer Immunol Immunother, 30, 5, 277-282. 
Whiteman, D.C., Whiteman, C.A., and Green, A.C. (2001). Childhood sun exposure as a risk factor for melanoma: a systematic review of epidemiologic studies. Cancer Causes Control, 12, 1, 69-82.

Wiemann, K., Mittrucker, H.W., Feger, U., Welte, S.A., Yokoyama, W.M., Spies, T., Rammensee, H.G., and Steinle, A. (2005). Systemic NKG2D down-regulation impairs NK and CD8 T cell responses in vivo. J Immunol, 175, 2, 720-729.

Xu, D., Gu, P., Pan, P.Y., Li, Q., Sato, A.I., and Chen, S.H. (2004). NK and CD8+ T cellmediated eradication of poorly immunogenic B16-F10 melanoma by the combined action of IL-12 gene therapy and 4-1BB costimulation. Int J Cancer, 109, 4, 499-506.

Yajima, T., Nishimura, H., Wajjwalku, W., Harada, M., Kuwano, H., and Yoshikai, Y. (2002). Overexpression of interleukin-15 in vivo enhances antitumor activity against MHC class I-negative and -positive malignant melanoma through augmented NK activity and cytotoxic T-cell response. Int J Cancer, 99, 4, 573-578.

Yang, Q., Hokland, M.E., Bryant, J.L., Zhang, Y., Nannmark, U., Watkins, S.C., Goldfarb, R.H., Herberman, R.B., and Basse, P.H. (2003). Tumor-localization by adoptively transferred, interleukin-2-activated NK cells leads to destruction of well-established lung metastases. Int J Cancer, 105, 4, 512-519.

Yee, C., Thompson, J.A., Byrd, D., Riddell, S.R., Roche, P., Celis, E., and Greenberg, P.D. (2002). Adoptive $T$ cell therapy using antigen-specific CD8+ T cell clones for the treatment of patients with metastatic melanoma: in vivo persistence, migration, and antitumor effect of transferred T cells. Proc Natl Acad Sci U S A, 99, 25, 16168-16173.

Yu, X., Harden, K., Gonzalez, L.C., Francesco, M., Chiang, E., Irving, B., Tom, I., Ivelja, S., Refino, C.J., Clark, H., Eaton, D., and Grogan, J.L. (2009). The surface protein TIGIT suppresses $\mathrm{T}$ cell activation by promoting the generation of mature immunoregulatory dendritic cells. Nat Immunol, 10, 1, 48-57.

Zaidi, M.R., Davis, S., Noonan, F.P., Graff-Cherry, C., Hawley, T.S., Walker, R.L., Feigenbaum, L., Fuchs, E., Lyakh, L., Young, H.A., Hornyak, T.J., Arnheiter, H., Trinchieri, G., Meltzer, P.S., De Fabo, E.C., and Merlino, G. (2011). Interferongamma links ultraviolet radiation to melanomagenesis in mice. Nature, 469, 7331, 548-553.

Zitvogel, L., Tesniere, A., and Kroemer, G. (2006). Cancer despite immunosurveillance: immunoselection and immunosubversion. Nat Rev Immunol, 6, 10, 715-727. 


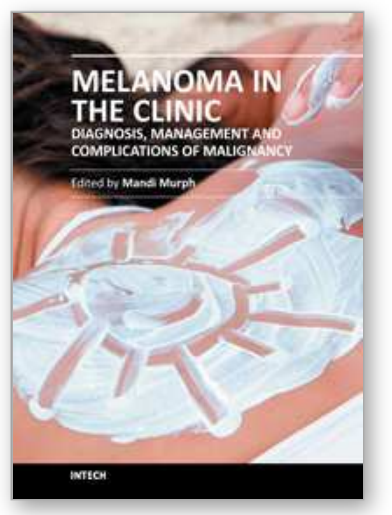

\section{Melanoma in the Clinic - Diagnosis, Management and Complications of Malignancy}

Edited by Prof. Mandi Murph

ISBN 978-953-307-571-6

Hard cover, 310 pages

Publisher InTech

Published online 23, August, 2011

Published in print edition August, 2011

This book provides an excellent overview of how melanoma is treated in the clinic. Since oncologists and clinicians across the globe contributed to this book, each area also explores the unique burdens that geographical areas experience from melanoma subtypes and how these are treated in different settings. It also includes several chapters that illustrate novel methods for diagnosing melanoma in the clinic using new technologies, which are likely to significantly improve outcomes. Several chapters cover surgical techniques and other present very rare or challenging clinical cases of melanoma and how these were treated. The book is geared towards informing clinicians and even patients how melanoma arises, what tools are available and which decisions need to be made by patients and their families in order to treat this devastating disease.

\section{How to reference}

In order to correctly reference this scholarly work, feel free to copy and paste the following:

Tadepally Lakshmikanth and Maria H. Johansson (2011). Current Perspectives on Immunomodulation of NK Cells in Melanoma, Melanoma in the Clinic - Diagnosis, Management and Complications of Malignancy, Prof. Mandi Murph (Ed.), ISBN: 978-953-307-571-6, InTech, Available from:

http://www.intechopen.com/books/melanoma-in-the-clinic-diagnosis-management-and-complications-ofmalignancy/current-perspectives-on-immunomodulation-of-nk-cells-in-melanoma

\section{INTECH}

open science | open minds

\author{
InTech Europe \\ University Campus STeP Ri \\ Slavka Krautzeka 83/A \\ 51000 Rijeka, Croatia \\ Phone: +385 (51) 770447 \\ Fax: +385 (51) 686166 \\ www.intechopen.com
}

\author{
InTech China \\ Unit 405, Office Block, Hotel Equatorial Shanghai \\ No.65, Yan An Road (West), Shanghai, 200040, China \\ 中国上海市延安西路65号上海国际贵都大饭店办公楼 405 单元 \\ Phone: +86-21-62489820 \\ Fax: +86-21-62489821
}


(C) 2011 The Author(s). Licensee IntechOpen. This chapter is distributed under the terms of the Creative Commons Attribution-NonCommercialShareAlike-3.0 License, which permits use, distribution and reproduction for non-commercial purposes, provided the original is properly cited and derivative works building on this content are distributed under the same license. 